\title{
Exploratory Models of Intersite Variability in Mid to Late Holocene Central Alaska
}

\author{
B.A. POTTER ${ }^{1}$
}

\author{
(Received 27 November 2007; accepted in revised form 10 March 2008)
}

\begin{abstract}
Interrelated aspects of technology, site structure, and subsistence patterns in central Alaska are synthesized using a comprehensive database of radiocarbon-dated components. Microblade technology is examined with respect to broad patterns of technology, settlement, and subsistence. Striking changes in the archaeological record during the Late Holocene ( 1000 cal $\mathrm{BP}$ ), including the loss of microblades, are explored through three general models: technological and economic change within existing populations, population replacement or assimilation, and taphonomic bias. The evidence most strongly supports the first: a shift from multiseasonal large mammal hunting strategies with associated high residential mobility to exploitation of seasonally overabundant resources (caribou, fish) and increased logistical mobility and reliance on storage.
\end{abstract}

Key words: Alaska, intersite variability, microblade technology, bison extirpation, Subarctic prehistory, subsistence economy, land-use strategies, Holocene

RÉSUMÉ. Les aspects interdépendants de la technologie, de la structure des sites et des modèles de subsistance dans le centre de l'Alaska sont synthétisés en s'appuyant sur une banque de données exhaustives de composantes datées au radiocarbone. La technologie des microlames est examinée par rapport aux modèles élargis en matière de technologie, d'établissement et de subsistance. Des changements marquants sur le plan de l'enregistrement archéologique du Holocène supérieur ( 1000 cal. BP), dont la perte des microlames, sont explorés à la lumière de trois modèles généraux : le changement technologique et économique au sein des populations existantes, l'assimilation ou le remplacement de la population, et l'écart taphonomique. Les éléments probants viennent surtout appuyer le premier modèle : le passage de stratégies de chasse multisaisonnière de gros mammifères accompagné d'une grande mobilité résidentielle à l'exploitation des ressources saisonnières surabondantes (le caribou, le poisson) accompagnée d'une mobilité logistique accrue et d'une dépendance du stockage.

Mots clés : Alaska, variabilité intersite, technologie des microlames, extirpation du bison, préhistoire subarctique, économie de subsistance, stratégies d'utilisation des terres, Holocène

Traduit pour la revue Arctic par Nicole Giguère.

\section{INTRODUCTION}

Archaeological investigations in Interior Alaska have multiplied since the 1970 s, resulting in the discovery of numerous sites in varying surface and subsurface contexts. Many surveyed sites remain buried in the gray literature, and little synthetic work has been attempted (but see Dixon, 1985; Sheppard et al., 1991; and Potter, 2004a). That the growth in empirical data has not been matched by a similar increase in our understanding of the prehistory in this region is particularly evident in our models of prehistoric change in this region. Basic cultural historical schemes remain almost unchanged since their original proposition (Cook and McKennan, 1970; see also Bacon, 1987) and are often constrained by normative views of culture (for example, the view that archaeological variability is primarily constrained by culturally derived mental templates). This perspective offers limited avenues for developing and testing hypotheses about land use and cultural change through time.
Several ambiguities exist in the archaeology of this region, including persistence of microblade technology in the Late Holocene alongside more recent tool forms and the emergence of the Athabascan Tradition (Shinkwin, 1979; Dixon, 1985). Mid-Holocene (and earlier) sites throughout the region are typically short-term camps or stations associated with a diverse flaked stone technology, including numerous formal tool classes like microblades. After $\sim 1000$ cal BP, substantial habitation and storage features first occur, associated with reduction of flaked stone technology, increased importance of organic technology, and use of copper. What precipitated this transformation of technology and settlement patterns within the region? This transition bridged the little-understood Northern Archaic Tradition and the late prehistoric Athabascan Tradition (with clear cultural links to protohistoric and historic Athabascans). Was this transformation due to migration of new peoples into the region, diffusion of new technologies, or changes in adaptive strategies of people living in this region? How do microblades fit into the

${ }^{1}$ Department of Anthropology, University of Alaska Fairbanks, 310 Eielson Building, Fairbanks, Alaska 99775, USA; ffbap@uaf.edu

(C) The Arctic Institute of North America 


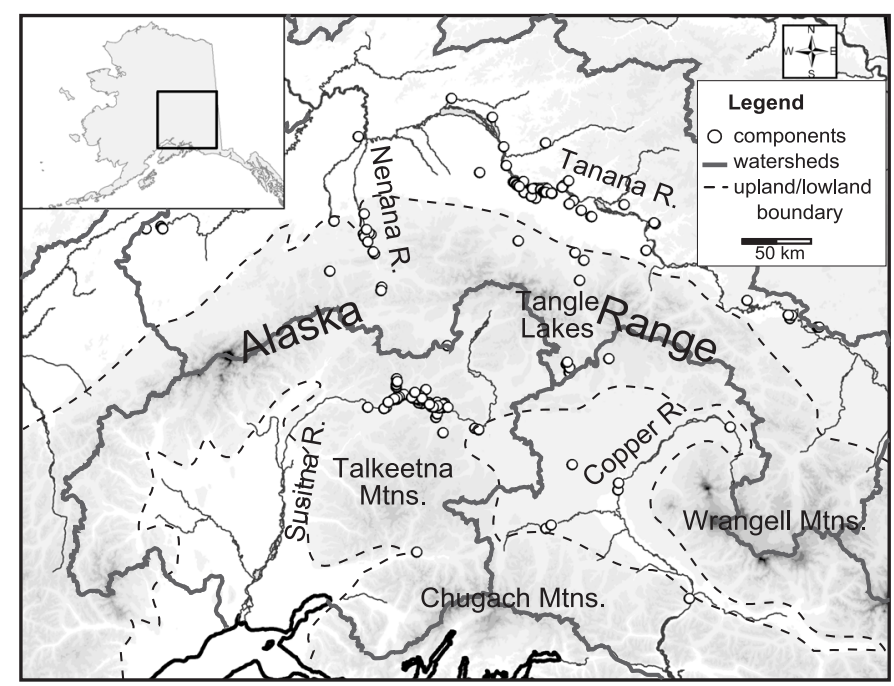

FIG. 1. Map of the study area, showing dated archaeological components (272 components from 181 sites).

broader technological systems of Holocene complexes? Is there a separate Late Denali Complex, distinct from the Late Pleistocene/Early Holocene Denali Complex (West, 1967, 1975; Dixon, 1985)?

Understanding this ambiguity is important because ethnographic and ethnohistoric data can be brought to bear only on the latest prehistoric manifestation in central Alaska, whereas the earlier archaeological complexes appear very different. Athabascan prehistory has been notoriously difficult to reconstruct given poor organic preservation and the lack of technological continuity with earlier archaeological cultures (Shinkwin, 1977). Understanding the transition from late prehistoric to ethnographically known groups is important for a variety of reasons: to allow linkage to more thoroughly understood cultural systems, and to better understand the integration of material culture with social structure and ideology. This transition is thus qualitatively different from earlier transitions between prehistoric groups where we have no such linkages.

Many well-known factors can condition assemblage variability beyond normative perspectives of cultural determinism, including seasonal variability, land use strategies, and role of storage facilities, as well as larger-scale factors like climate change and long-term changes in biodiversity (Binford, 1973, 1979; Torrence, 1983; Bamforth, 1986, 1991; Shott, 1986; Odell, 1988, 1996; Andrefsky, 1994; Kuhn, 1994). Large- and small-scale environmental variables are directly mediated by human adaptive strategies, encompassing technology, subsistence, and settlement strategies. Explaining assemblage variability solely in terms of normative culture concepts limits our ability to explore the relationships among environmental variables and human adaptation in this region. The research presented here attempts to understand assemblage variability by moving beyond lithic typology and addressing patterns in technology, economy, and site structure in this region.
To this end, this paper provides (1) a synthesis of existing archaeological data for the best-sampled portion of Interior Alaska (the Tanana, Susitna, and Copper River watersheds) to better situate the problem of Holocene assemblage and site structural variability (Fig. 1), and (2) a number of explanatory models consistent with the observed patterns. Possibilities for testing these models are also discussed. The study area totals almost 93000 square miles $\left(240869 \mathrm{~km}^{2}\right)$, roughly the size of Minnesota. While the area is large, these three watersheds share a similar history of research (related to substantial development and site discovery), similar search images, climate, current vegetation and faunal distributions, and general physiography. Furthermore, these watersheds were inhabited by various Athabascan groups using relatively similar technology and subsistence/settlement systems.

\section{Background}

The disparity between mid-Holocene and Late Holocene assemblages has been widely noted (cf. Derry, 1975; Bacon, 1977; Holmes, 1977, 1986; Shinkwin, 1977, 1979; Workman, 1977; Clark, 1981). Holmes' (1986) cultural sequence at Lake Minchumina shows a clear technological break between recent Athabascans (Spruce Gum Phase) and the earlier Minchumina Tradition (2600-950 cal BP). Numerous components dated to the mid-Holocene ( 60001000 cal BP) contain well-developed flaked stone industries, including microblades struck from prepared cores and bifacial projectile points (e.g., side-notched, stemmed, oblanceolate, and lanceolate varieties) (Bacon, 1977; Dixon, 1985). After $\sim 1000$ cal BP, microblade technology and most formal flaked stone tools (especially large bifacial forms) are rare or absent. Maschner's (1989) summary shows clear reduction in emphasis on flaked cryptocrystalline tools and flakes between $\sim 800$ and $100 \mathrm{cal}$ BP. In the Late Prehistoric Period (sensu Workman, 1977), flaked stone wedges, end scrapers, and expedient boulder spall artifacts (commonly termed $t c i$-thos) are common. Larger bifacial projectile points are replaced by diminutive stemmed points, termed "Kavik points," but organic barbed and unbarbed points dominate hunting implements. Flaked stone technology was not known to Tanana ethnographic informants in the 1930s (Shinkwin, 1979).

Evidence for technological continuity through the Late Holocene is equivocal. Cook $(1969,1989)$ posits continuity at Healy Lake Village site for the last 10000 years, but the chronological gap between Level 1 and the historic occupation and lack of convincing typological links argues against this (see Shinkwin, 1979). In nearby regions, varying sequences have linked recent Athabascan groups with Late Prehistoric occupations, including a 1200-year sequence at Klo-kut (Morlan, 1973a). Others argue for general continuity between mid-Holocene cultures and Athabascans at Lake Minchumina (Holmes, 1986) and in the Southwest Yukon (Workman, 1978). 
Attempts to understand any particular technology (such as microblades) as a part of overall assemblage variability are often situated within cultural historical perspectives. Briefly summarized, cultural complexes are created on the basis of shared attributes of artifact types/classes and a fossile directeur approach, where one or two types are sufficient to establish connections between sites. The utility of these often provisional constructs for exploring cultural change is arguably limited (see review in Bever, 2001 and Clark, 2001). Many of these complexes have been defined primarily on the presence or absence of microblade technology and bifacial point forms. Two of the most influential types, Chindadn points and notched bifaces, have considerable variability and likely reflect multiple functional types (Workman, 1978; Holmes, 2001).

Binford (1983) argues that cultural historical approaches may obscure actual patterning in assemblage variability. One way to move beyond these limitations is to examine assemblage variability with respect to economic and site structural variability. Microblade technology is not limited to a single period of human occupation, and it is important to understand how this technology was used with respect to other technology, settlement strategies and site structure, and subsistence.

One important implication of continuity in microblade technology lies in its long history among high-latitude populations in very different environments. This technology was widespread in northeast Asia (Siberia, Russian Far East, northern China, Tibet, Korea, and Japan) from the last glacial maximum (Slobodin, 2001; Vasil'ev, 2001). Microlithic technology may have played a role in very high residential mobility that allowed for rapid colonization of high-latitude terrain (Goebel, 1999). There is no consensus on microblade function, and there may be considerable functional variability within and among cultural systems. Therefore, it is important to understand microblade use in systemic contexts.

While some have argued that notched biface assemblages are associated with populations distinct from those using microblade technology in certain areas (Anderson, 1988 for Northwest Alaska and Workman, 1978 for Southwest Yukon Territory), an ever-increasing body of evidence indicates associations between these technologies in this region (see Cook and Gillispie, 1986). Potential relationships of this co-occurrence of multiple weapon systems (bifacial and microblade/composite points) to economy and land-use strategies must be addressed.

In addition to the new archaeological data from this region presented here, important new data have recently been published on prehistoric weapon systems from ice patch archaeology in the adjacent southwest Yukon Territory. The unprecedented preservation of the organic components of these weapon systems is particularly relevant for the western Subarctic, given the general lack of organic preservation in boreal forest environments. Bow and arrow technology completely replaces throwing dart weapon systems soon after its introduction at $\sim 1300$ cal BP (Hare et al., 2004). There is a relationship between the point material and the weapon system: $90 \%$ of dart points are bifaces (notched, stemmed, and lanceolate forms) and only two are made of antler, whereas $100 \%$ of the arrow points are either antler or bone (Hare et al., 2004). Only a single slotted antler dart point was recovered (interpreted by the authors to receive microblades, though none were found associated) (Hare et al., 2004). These numbers suggest a long-standing preference for bifacial dart tips throughout the Holocene (from 9300 to $1300 \mathrm{cal} \mathrm{BP}$ ). These patterns are integrated below into models of technological change.

\section{METHODS}

\section{Database Description}

This analytical database, developed from Alaska Heritage Resource Survey (AHRS) data, is limited to sites with published references. The empirical data used here consist of all available dated components in the region, totaling 272 components (or occupations) from 181 sites (described in Potter, 2008). All primary references for these sites are provided in the Appendix (Table A1). Component delineation and dating generally follow the original investigator's interpretation (see Appendix for exceptions). Two sets of data were defined: Database 1 (DB1), comprising 160 components with directly associated radiocarbon dates (on strata or cultural features); and Database 2 (DB2), comprising (a) 112 components with estimated ages (stratigraphic bracketing dates, associated tephras, etc.) and (b) all DB1 components (thus, totaling 272 components).

For DB1 components, multiple dates on single stratigraphic contexts were averaged following Ward and Wilson (1978) using the Calib 5 program (Stuiver and Reimer, 1993, Version 5) to provide a single radiometric age estimate. The estimated ages were calibrated using Calib 5 with the IntCal04 terrestrial calibration curve (Reimer et al., 2004). The median of each date range was taken, and the components were grouped into 1000 calendar year intervals. While the single age estimators lack precision, lumping components by broad intervals partially mitigates this problem.

For DB2 components with estimated ages, the midpoint of the calibrated chronological range was used as the age estimator, and components were also grouped by 1000 calendar year intervals. Syntheses based on DB 1 and DB2 are distinguished below, but in all cases DB2 sample results were similar to DB1 sample results.

Variables were gathered from the primary literature for each component and include total excavated area, landform (lakeshore, alluvial terrace, etc.), total flaked stone assemblage size, and the presence or absence of microblade technology, notched bifaces, projectile points, cultural depressions, and associated fauna. Notched bifaces are 
included here because of their role as a hallmark of the Northern Archaic tradition (Anderson, 1968; Dixon, 1985).

Faunal presence/absence data from the literature were collated at three levels: (1) faunal presence vs. absence, (2) large vs. small mammal, and (3) individual taxa (identified to genus or species for mammals and class for fish and birds). The term "large mammal" refers here to ungulates: bison, wapiti, moose, caribou, sheep, and unidentified large mammals (as identified by each original investigator), while "small mammal" refers to other medium to very small mammals (hare, ground squirrel, marmot, beaver, otter, porcupine).

Relatively few sites in the study area have been excavated (only 18 sites have more than $50 \mathrm{~m}^{2}$ excavated, compared to 104 sites with less than $10 \mathrm{~m}^{2}$ excavated; the overall median is $3.9 \mathrm{~m}^{2}$ excavated). Sites chosen for excavation tend to be larger and more complex, with the possibility of palimpsests (many overlapping occupations). The larger sample size evaluated here may better reflect underlying prehistoric behavior patterns. To mitigate the effect of the generally small samples of stone tools and faunal remains per site, variables were largely confined to presence/absence, and sample size effects were evaluated.

\section{Analytical Methods}

Given the coarse-grained nature of the dataset and the broad level of synthesis attempted here, differences among variables and groups are assessed through Pearson chisquare analysis of $2 \times 2$ tables, which tests the hypothesis of no association (null) or association (alternate) of columns and rows. Cells represent components enumerated by grouping variables (e.g., presence of a particular taxon or technology). The reported chi-square value is the Yates chi-square corrected for continuity. $P$-values refer to the probability of non-association of the categorical variables (i.e., if $p<0.05$, the variables are inferred to be associated). Cramer's V values measure the strength of the association between nominal categorical variables (ranging between -1 and 1 ). For $2 \times 2$ tables where any of the cells have expected frequencies of 5 or less, the Fisher Exact Test (one-tailed $p$-values) is used. Component comparisons yielded baseline data on covariation of lithic, faunal, and site structural characteristics. General patterns of chronology, technology, site structure, and subsistence were identified. Various models were abductively developed to explain these patterns.

\section{Data Limitations}

This research presents a conceptual framework to organize and explore relationships among various forms of archaeological data and to generate and test hypotheses at various spatial and temporal scales without recourse to monolithic cultural constructs. However, some limitations are inherent in the database and analytical methods. The extent to which the total known sample of sites suitably reflects the underlying population is currently unknown, though numerous resource management and academic projects in the region have discovered components from every period of human occupation of North America. A recent survey through the mid-Tanana basin resulted in the dating of 36 components without bias for expected age (Potter et al., 2007b); the resulting distribution matches the overall DB1 distribution, suggesting the inferences derived from these data may not be overly biased with respect to age.

Most sites have been found in overlook positions and are typically inferred as short-term camps or stations. This topographic distribution may not adequately reflect actual variation in site locations or site structure and function. In addition, Subarctic site formation and disturbance processes may also affect spatial and temporal distribution of components (Ives, 1990). However, that portion of the overall settlement strategies reflected in these short-term camps/stations can be examined for changes through time.

Component age estimates should be viewed as tentative given the limited number of large-scale excavations (with refit controls), multiple dates on cultural features, and other uncertainties.

Limitations in archaeological knowledge in Interior Alaska must also be acknowledged. Systemic tool use, seasonal variability in subsistence and lithic procurement strategies, settlement patterns, and basic population parameters are virtually unknown. Therefore, this synthesis includes only a few basic lithic characters (microblades, notched bifaces, and projectile points) that are used as cultural diagnostics. Component comparisons are aided by similar search images, survey and testing strategies, and typological and technological nomenclature used by researchers since the 1970s (e.g., Morlan, 1973b; Workman, 1978; Powers et al., 1983).

By excluding all non-radiocarbon dated components, this database under-represents the most recent period (post 200 cal BP), as C14 dates may not be run when evidence exists (such as trade beads, etc.) for protohistoric or historic age. However, as the time period of concern extends to 200 cal BP, when habitation and storage features typical of Athabascan cultures are established (or at least recognized), this under-representation does not affect the analysis. Given these limitations, these data provide important provisional baseline data on covariation among lithics, fauna, and site structure.

\section{RESULTS}

\section{Chronology}

The absolute number of DB1 (directly dated) components per 1000 years cal BP is illustrated in Figure 2. Relative increases in component abundance during the $14000-13000$ cal BP, $12000-10000 \mathrm{cal} \mathrm{BP}$, and $9000-$ 8000 cal BP and decreases at 13000-12000 and 10000- 


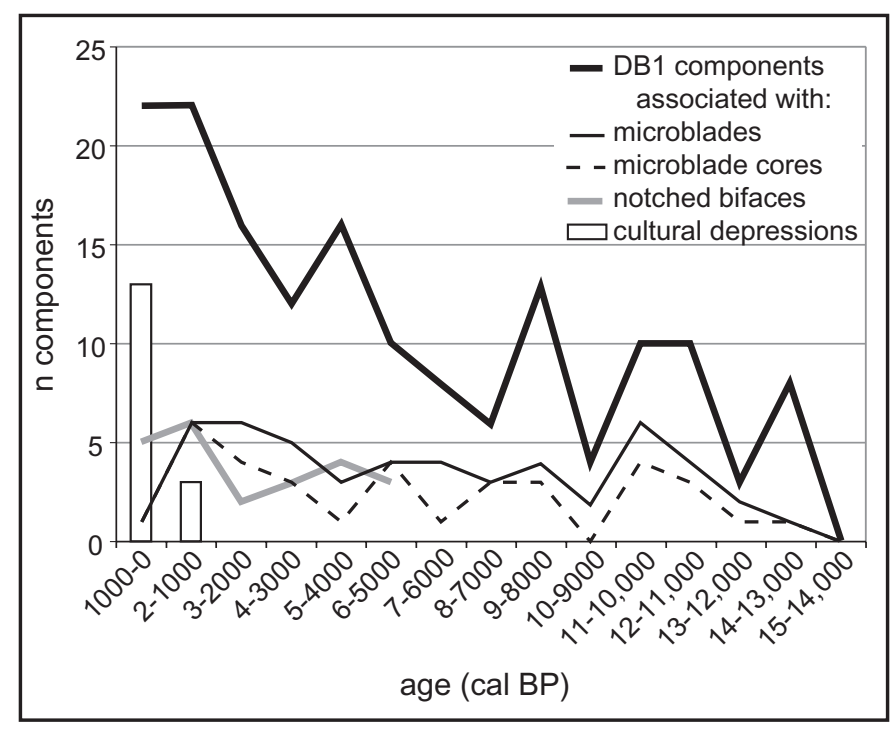

FIG. 2. Temporal distribution of DB1 components $(n=160)$, technology, and cultural depressions (semi-subterranean houses, cache pits).

9000 cal BP intervals are apparent. The two periods of fewer components may reflect lower populations and lower carrying capacity related to effects of the Younger Dryas stadial and the first post-glacial spruce forest expansion in the region (Ager and Brubaker, 1985; Overpeck et al., 1989). The mid-late Holocene record, after $6000 \mathrm{cal} \mathrm{BP}$, is characterized by increasing component abundance, perhaps related to increasing archaeological visibility (though there is a small decrease at $4000-3000 \mathrm{cal} \mathrm{BP}$ ). The lower component abundance at the $1000-0$ cal BP period reflects radiocarbon sampling bias, as many sites were adequately dated with Euro-American trade goods (e.g., beads, iron), like Dakah Den'in (Shinkwin, 1979) and Paxson Lake (Ketz, 1983). If these protohistoric and early historic sites were added, the component population curve would increase dramatically over the $2000-1000$ cal BP period sample.

These data are consistent with a number of demographic scenarios, including population replacement at $\sim 5800$ cal BP (associated with the Northern Archaic Tradition), changes in size and structure of existing populations related to various adaptive economic strategies, or taphonomic factors affecting site preservation. However, at this coarse resolution, no breaks or major trends indicating population decline or extirpation are evident for the last $\sim 6000$ years.

\section{Technology}

Microblade technology is ubiquitous in this region, present from the earliest known occupation (Swan Point Cultural Zone (CZ) 4, Holmes, 2001), throughout the Holocene until $\sim 1000$ cal BP, generally paralleling overall component abundance (Figs. 2 and 3). Microblade-bearing components comprise $\sim 20-70 \%$ of DB 1 components per 1000 year intervals except for the last 1000 years,

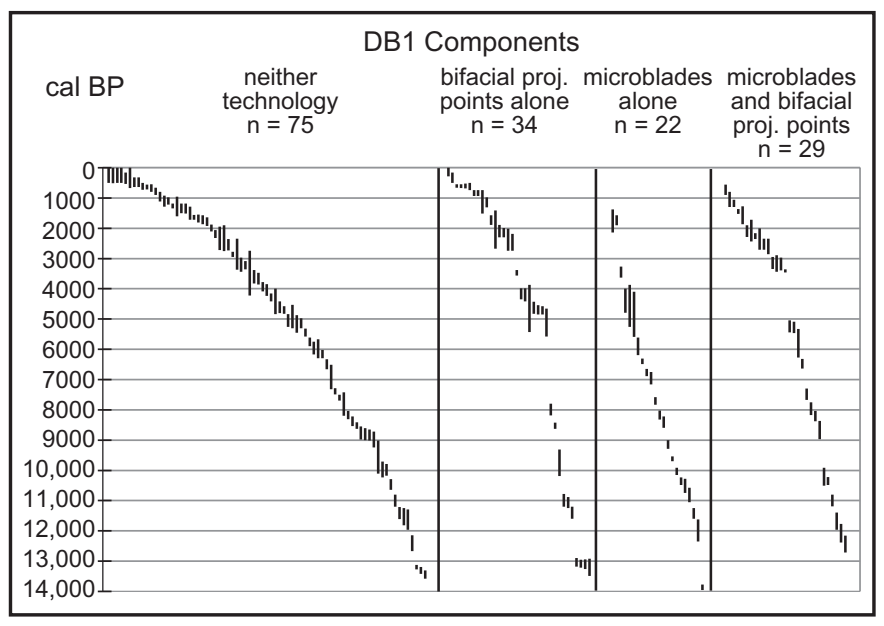

FIG. 3. Calibrated age ranges (2 SD) of DB1 components $(n=160)$, ordered by associated technology and age.

where they drop to $5 \%$ (represented at only one component, Healy Lake Village Level 1, dated to 962-675 cal $\mathrm{BP})$. A similar pattern is evidenced with microblade cores within DB1 components (Fig. 3) and microblade technology within DB2 components. While some sites like Healy Lake and Campus may be affected by taphonomic mixing of cultural layers (Mobley, 1991; Hamilton and Goebel, 1999), data from the stratified Broken Mammoth and Swan Point sites unequivocally link microblade technology with secure Late Holocene radiocarbon dates (Holmes, 1996, 2004; Yesner and Pearson, 2002; see also data in Shinkwin, 1979; Holmes, 1986; Betts, 1987 for data on recent microblade sites). While microcore morphology in this region exhibits variability, wedge-shaped microcores are found throughout the Holocene. The data presented here demonstrate continuity of microblade technology throughout the Holocene until around $1000 \mathrm{cal}$ BP.

Within this continuity there may be differences in microblade use from earlier to later Holocene. Between $\sim 3500$ and 1000 cal BP, microblades overwhelmingly cooccur with bifacial projectile points $(\mathrm{n}=15$ components vs. 3 components with microblades without bifacial points), whereas in earlier periods, these two types are more evenly split (19 vs. 14), possibly indicating different land-use strategies (Fig. 3).

Microblade recovery does seem to be affected by sampled area. When limiting the sample to all components with more than $50 \mathrm{~m}^{2}$ excavated $(\mathrm{n}=51)$, microblades averaged $57 \%$ of all components per 1000 calibrated years BP, $57 \%$ of components from 3000 to $2000 \mathrm{cal} \mathrm{BP}$, and $100 \%$ of components from 2000 to $1000 \mathrm{cal} \mathrm{BP}$, dropping to $14 \%$ of components under 1000 cal BP (the single Healy Lake component). Given that microblades tend to be discarded in small discrete clusters that may be missed in sites with limited excavation (see Potter, 2005), the patterns observed here likely under-represent microblade occurrence.

Notched bifaces are represented from $\sim 5800$ to $300 \mathrm{cal}$ BP. Of the 18 dated DB 1 components older than $1000 \mathrm{cal}$ 
BP with notched bifaces, over half $(n=10)$ also contain microblade technology. No temporal trend in correlation is seen, and both technologies co-occur from the earliest components with notched bifaces (Butte Lake $\mathrm{C} 2$ and Swan Point CZ1B) to some of the latest (Healy Lake Level 1, Lake Minchumina Level 1, Swan Point CZ1A). This pattern suggests that a single cultural tradition is represented in the later Holocene components in this region.

Site function almost certainly affects tool discard behaviour, and this effect may be evident in these data. Several sites in the region associated with primary lithic reduction tend not to have microblade technology, including Landmark Gap and Little Delta River \#3 (Mobley, 1982; Higgs et al., 1999; Potter et al., 2007c). The absence of microblade technology does not reflect a "cultural adaptation" present in all toolkits or discarded at all sites, but reflects the use of composite and bifacial points for specific purposes or associated with specific activities that may not have occurred at a specific site.

The evidence for Holocene technological continuity presented here is supported by technological and typological analyses at individual sites. Many tool classes and types, such as wedge-shaped microcores, flake burins, various scraper forms, lanceolate bifaces, and boulder spall scrapers, are relatively unchanged from the Late Pleistocene to the Late Holocene (Holmes and Bacon, 1982; Holmes et al., 1996; Bowers, 1999). Of particular importance here is the co-occurrence of microblades (inferred to be composite point insets) and bifacial points (Fig. 3). The implications for the co-occurrence of multiple weapon systems are evaluated below.

\section{Site Structure}

Sites in the study area can be divided into two groups, one representing surface or buried lithic scatters with or without unlined firepits (generally interpreted to be outdoor hearths) situated on positive landforms with overlook potential, and the other representing cultural depressions (semi-subterranean houses, cache pits) near lakes and clearwater streams at lower relative elevations above the surrounding terrain. There is no current evidence for semisubterranean houses or storage features (such as caches) before $\sim 1200$ cal BP, with the possible exception of XMH035 , dated to $\sim 5000$ cal BP. There was no site report produced, and the AHRS record states: "excavation also reportedly produced evidence of an oval dwelling," without explicitly identifying it as a depression. The absence of obvious habitation sites older than $1200 \mathrm{cal}$ BP in this region is remarkable, even assuming increased residential mobility in the earlier Holocene (Kelly and Todd, 1988; Goebel, 1999). Few habitation sites are found in Subarctic regions of Northeastern Siberia and the Russian Far East in the Late Pleistocene/Early Holocene; a notable exception is Ushki Lake Levels 6 and 7 (Goebel and Slobodin, 1999).

While few prehistoric settlement system models for central Alaska have been advanced, Guthrie (1983a) suggested a settlement system for the Nenana valley composed of a central base or residential camp and outlying spike camps where game processing and tool maintenance occurred. Most pre-1200 cal BP components would be considered spike camps or work stations depending on the variable presence/absence of faunal remains and features. A residential base camp would presumably have semisubterranean features similar to those at Ushki-1 to allow winter shelter, but none have been found before the latest Holocene. Yesner (1996) notes that this absence could be due to location of base camps along major rivers in valley bottoms, at sites subsequently destroyed through channel changes in the active floodplain. However, ethnographic data indicate Athabascan preference for habitation sites adjacent to clearwater streams and lakes, which arguably undergo less destruction than do glacially fed braided rivers. Numerous surveys have been completed in the region, and a wide variety of environments have been sampled, including numerous lake and stream edges and alluvial terrace edges above abandoned floodplain alluvium, with no evidence for older semi-subterranean houses (see Potter et al., 2002, 2007b).

While taphonomy may affect habitation site preservation, another possibility should be considered. Short-term, open-air camps may have been used as residences, and early prehistoric populations may have been more residentially mobile than earlier thought (see Mason et al., 2001). Reasonable expectations for residential base camps would include relatively high diversity of tool types, high number of lithic raw material types, and features relating to dwelling structures (Carlson, 1979; Binford, 1980). Type 2 dwelling structures observed at Ushki 1, level 6-described as surface houses with centrally located, rock-lined hearths without entrance tunnels and inferred to be summer huts (Dikov, 1977, cited in Goebel and Slobodin, 1999:133-134)—may be useful models for possible dwelling features in the study area. Limited evidence exists for stone-lined features in this region, though Wilson and Slobodina (2007) have recently recorded stone tent rings associated with mid-Holocene Northern Archaic technology in the Brooks Range, to the north of the study area. While Goebel and Powers (1989) suggested that circular spatial distributions of artifacts around centrally located unlined hearths at Walker Road C1 may be evidence for tent-like surface structures, analysis by Higgs (1992) shows extensive lithic refits between all concentrations, suggesting they may not have been produced within structures. Large cobbles were found at Owl Ridge and Gerstle River C1, but the former site has had very little horizontal excavation (Phippen, 1988), and the cobbles at the latter site were interpreted to be of colluvial origin (Potter, 2005). However, Healy Lake Village, Garden, and Lake Minchumina components may represent base camps, as all three yielded a high diversity of tool classes and wide variety of lithic material types (Cook, 1969; Holmes, 1986).

This potential dichotomy between lakeshores vs. elevated landform settings may affect technological distributions. Microblade technology has closer associations 
with lakeshore settings: microblades were found in $73 \%$ of lakeshore components dated earlier than $1000 \mathrm{cal} \mathrm{BP}$, vs. only $25 \%$ of non-lakeshore components (chi-square $=$ $14.4, p=0.000$, Cramer's V $=0.27$ ). This distribution echoes the results of Sheppard et al. (1991). While this association does not indicate why microblades and lakeshores are associated, it does suggest that microblades are not randomly distributed in all areas on the landscape as expected in a normative model of microblade use.

In sum, evidence for seasonally specific residential or habitation sites (e.g., winter villages, fish camps) and storage facilities (indicating seasonally abundant resources and logistical organization) is present only after about 1200 cal BP, thus making it difficult to compare lithic and faunal assemblages between the ethnographic present and earlier periods.

\section{Subsistence}

Faunal remains offer a wealth of information about site function, economy, and settlement strategies, and the record for the study area is quite robust (compared with other areas like the Brooks Range or Northwest Alaska, where preservation is more limited). Of the 272 DB2 components, a remarkable 128 (48\%) contained faunal remains. Of these 128 components, 44 were described as unidentified (typically composed of small calcined/burned fragments) or unidentified mammal (medium to large size), and thus had limited analytical potential. The remaining 84 components were analyzed further. Table 1 lists components with some level of faunal identification, and Table 2 lists components with more specific identifications. While the relatively larger number of post-3000 cal BP components likely reflects a taphonomic bias against preservation, these data span the record of occupation, with 14 components older than $10000 \mathrm{cal}$ BP.

The most striking pattern is the broad spectrum of resource use throughout the record; large and small mammals, birds, and fish are represented from the earliest to the latest components. Fish, and to a lesser extent birds and small mammals, are present at fewer sites in the midHolocene; however, this result may be due to sampling. Only 11 components are known between 10000 and 5000 cal BP, and the proportions of small mammals remain roughly the same (found at around $25-50 \%$ of components during this period). On the basis of these data, we may conclude that no major resource group was ignored, though small mammals and fish use may have increased after 5000 cal BP. However, large mammals still dominate the entire record (found at $93 \%$ of all components with fauna).

Caribou and moose dominate the large mammal record, though bison and wapiti are well represented in the early Holocene (Table 2). The date of the shift from bison- and wapiti-dominated components to caribou and moose is difficult to infer given potential taphonomic factors (and possible misidentification of moose and wapiti remains), but given the presence of bison in Alaska until the last few hundred years (Stephenson et al., 2001), bison hunting may have been an important part of subsistence strategies throughout the Holocene. Additional support for late Holocene bison and wapiti predation include directly dated fauna associated with Yukon Territory ice patches: bison from $\sim 8300-2900$ cal BP and wapiti until $\sim 1400$ cal BP (Farnell et al., 2004).

The relationship between technology and subsistence can be directly explored through this database. Microbladebearing components are significantly associated with faunal remains (chi-square $=4.46, p=0.035$, Cramer's $V=0.15$ ) (Fig. 4A). When controlling for sample size $(n=43$ components dated earlier than $1000 \mathrm{cal} \mathrm{BP}$ with more than $50 \mathrm{~m}^{2}$ excavated), this relationship is even more pronounced (Fisher's Exact Test, $p=0.017$, Cramer's V = 0.38) (Fig. 4B). This pattern supports the contention that microblades were part of a hunting toolkit.

Having demonstrated the microblade-faunal association, it is important to assess associations with particular taxa. The sample sizes are small, so these associations should be viewed as provisional. Overall, microbladebearing components are more associated with most taxa, with the notable exception of caribou, which was found at $33 \%$ of microblade components versus $62 \%$ of nonmicroblade components (Fig. 5). Large-bodied ungulates are differentially positively associated with microblade technology (Fisher's Exact Test, bison, $p=0.044$; moose, $p=0.000$; and possibly wapiti, $p=0.089$ ), while smallerbodied ungulates have no such association (Fisher's Exact Test, caribou, $p=0.920$; sheep, $p=0.414$ ). Bison (found at $21 \%$ of microblade components with faunal remains vs. $8 \%$ of non-microblade components) and moose (33\% vs. $5 \%$ ) may illuminate microblade/composite point function. Put another way, $63 \%$ of all components with bison contain microblade technology, and only $25 \%$ (2 components) contain bifacial projectile points. Both of these components also contain microblade technology (Swan Point C2 and Broken Mammoth CZ3). If bison-microblade associations are present at Swan Point CZ3 and Campus, then 70\% of components with bison contain microblade technology. Only $11 \%$ of components with caribou contain microblade technology, compared with $38 \%$ that contain bifacial projectile points.

Notched bifaces are strongly associated with caribou, which are found at $78 \%$ of notched biface components with identifiable fauna (total $\mathrm{n}=9$, Fisher's Exact Test, $p=0.007$, Cramer's V $=0.20$ ), but there are none associated with bison or wapiti (Fig. 6A). Components with any projectile point type $(n=24)$ show a similar trend: they are associated with caribou, and to a lesser extent, with moose. When examining components by taxa, moose, bison, wapiti, and mammoth are more likely to be associated with microblade technology than with bifacial projectile points, while caribou, bear, and sheep are equally associated with microblades and projectile points (Fig. 6B). In sum, microblades appear to be closely associated with larger mammals (mammoth, bison, moose, and possibly wapiti), 
TABLE 1. DB2 component faunal assemblage summary.

\begin{tabular}{|c|c|c|c|c|c|c|}
\hline Period (cal BP) & All fauna & Mammals & Birds & Fish & Large Mammals & Small Mammals \\
\hline $1000-0$ & 21 & 21 & 3 & 5 & 19 & 11 \\
\hline $2000-1000$ & 17 & 17 & 1 & 4 & 15 & 4 \\
\hline $3000-2000$ & 9 & 9 & 1 & 2 & 8 & 4 \\
\hline $4000-3000$ & 5 & 5 & 1 & & 5 & 2 \\
\hline $5000-4000$ & 7 & 7 & 1 & & 7 & 3 \\
\hline $6000-5000$ & 1 & 1 & & & 1 & \\
\hline $7000-6000$ & 2 & 2 & 1 & 1 & 2 & 1 \\
\hline $8000-7000$ & 3 & 3 & & & 2 & 1 \\
\hline $9000-8000$ & 2 & 2 & 1 & & 2 & 1 \\
\hline $10000-9000$ & 3 & 3 & & & 3 & 1 \\
\hline $11000-10000$ & 4 & 4 & 1 & & 4 & 1 \\
\hline $12000-11000$ & 4 & 4 & 1 & & 4 & \\
\hline $13000-12000$ & 1 & 1 & & 1 & 1 & 1 \\
\hline $14000-13000$ & 5 & 5 & 3 & 1 & 5 & 2 \\
\hline Total & 84 & 84 & 14 & 14 & 78 & 32 \\
\hline
\end{tabular}

TABLE 2. DB2 components with identifiable fauna ${ }^{1}$ from the study area.

\begin{tabular}{|c|c|c|c|c|c|c|c|c|c|c|c|c|c|c|c|}
\hline $\begin{array}{l}\text { Period } \\
\text { (cal BP) }\end{array}$ & Caribou & Moose & Bison $^{2}$ & Wapiti & Sheep Mammoth ${ }^{3}$ & Hare & Beaver & Canid & Bear & Rodent ${ }^{4}$ & $\begin{array}{l}\text { Ground } \\
\text { squirrel }\end{array}$ & Marmot & Otter & Porcupine & Lynx \\
\hline $1000-0$ & 14 & 6 & & & 2 & 6 & 3 & 4 & 2 & 2 & 1 & 2 & 1 & & \\
\hline $2000-1000$ & 15 & 1 & & & & 2 & 3 & 2 & & & 1 & & & & \\
\hline $3000-2000$ & 6 & 1 & 1 & & & 2 & 3 & & 2 & & & & & & \\
\hline $4000-3000$ & 2 & 1 & $1 ?$ & & & 1 & 1 & 1 & 1 & & & & & & \\
\hline $5000-4000$ & 4 & 2 & & & & 1 & & & & & & & & 1 & 1 \\
\hline $6000-5000$ & & 1 & & & & & & & & & & & & & \\
\hline $7000-6000$ & 1 & & & & & & & & & 1 & & & & & \\
\hline $8000-7000$ & 1 & & & & & 1 & & & & & & & & & \\
\hline $9000-8000$ & 1 & 2 & 1 & 1 & & 1 & 1 & & & 1 & & & & & \\
\hline $10000-9000$ & 1 & & & & 1 & & & & 1 & & 1 & & & & \\
\hline $11000-10000$ & & & 2 & 1 & & & & & & & & & & & \\
\hline $12000-11000$ & & & $1+1$ ? & 1 & 1 & & & & & & & & & & \\
\hline $13000-12000$ & 1 & 1 & 1 & 1 & 1 & 1 & & 1 & & 1 & 1 & 1 & 1 & & \\
\hline $14000-13000$ & & 1 & 2 & 3 & 2 & 1 & & 1 & & 1 & 1 & 1 & 1 & & \\
\hline Total & 46 & 16 & 8 & 7 & 7 & 16 & 11 & 9 & 6 & 6 & 5 & 4 & 3 & 1 & 1 \\
\hline
\end{tabular}

${ }^{1}$ Scientific names: caribou (Rangifer tarandus), moose (Alces alces), bison (Bison sp.), wapiti (Cervus elaphus), sheep (Ovis dalli), mammoth (Mammuthus sp.), hare (primarily Lepus americanus), beaver (Castor canadensis), canids (foxes, wolves, and dogs), bear (primarily Ursus americanus), ground squirrel (Spermophilus sp.), marmot (Marmota broweri), otter (Lontra canadensis), porcupine (Erithizon dorsatum), and lynx (Lynx canadensis).

${ }^{2}$ Bison remains were found at the Campus site, but may not be associated with the dated component (Mobley, 1991), and bison was possibly identified at Swan Point CZ3 (Holmes, pers. comm. 2006).

${ }^{3}$ Mammoth dated to the occupation.

${ }^{4}$ Other (or unspecified) rodent.

${ }^{5}$ Single component assemblages dominate the 14 000-12 000 cal BP record (Broken Mammoth CZ3 and CZ4 respectively).

whereas notched bifaces (and projectile points in general) are closely associated with smaller game (particularly caribou).

\section{MODEL DEVELOPMENT}

The patterns presented in the synthesis above were used to develop the empirical generalizations summarized here. Microblade technology is present throughout the entire span of human occupation in the study area until around $1000 \mathrm{cal} \mathrm{BP}$, when microblades disappear from the record, along with many formal flaked stone tool forms. Bow and arrow technology was likely introduced into the region ca.
1300 cal BP. Site structure and inferred settlement and storage strategies appear to have changed at around that time, with earlier components characterized by high residential mobility, no formal storage features, and no apparent long-term habitations, and later components characterized by increased diversity in site types, increased logistical mobility, storage features, and seasonal habitation sites. Subsistence data indicate bison and wapiti hunting (within generalized economies that included fish, birds, and small mammals), with increased caribou and moose hunting after $\sim 5000 \mathrm{cal} \mathrm{BP}$, and possibly increased small game procurement after $\sim 4000 \mathrm{cal}$ BP. To explain these patterns, I have developed three models (or explanative scenarios). The first two are to some extent exclusive 


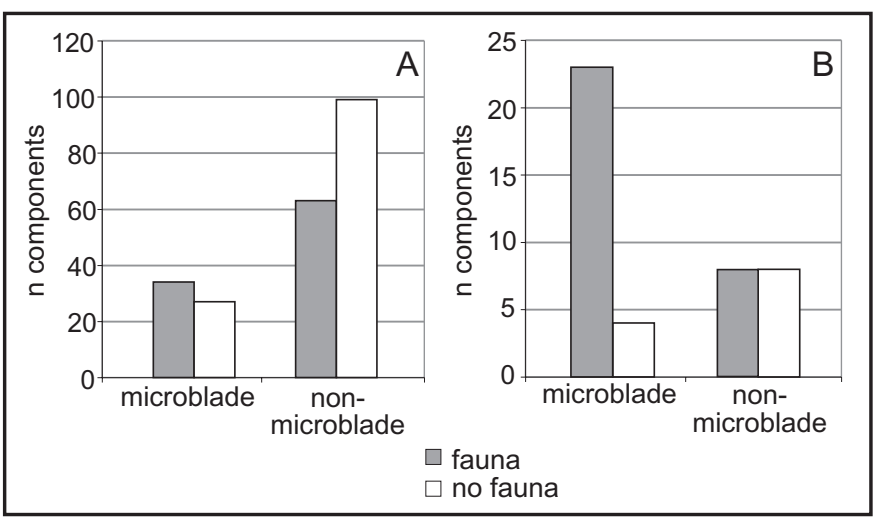

FIG. 4. Relationship of microblades and faunal remains. (A) DB2 components dated earlier than $1000 \mathrm{cal}$ BP with fauna/no fauna reported $(\mathrm{n}=223)$; (B) DB2 components dated earlier than $1000 \mathrm{cal} \mathrm{BP}$ and excavated area of over $50 \mathrm{~m}^{2}$, $\mathrm{n}=43$.

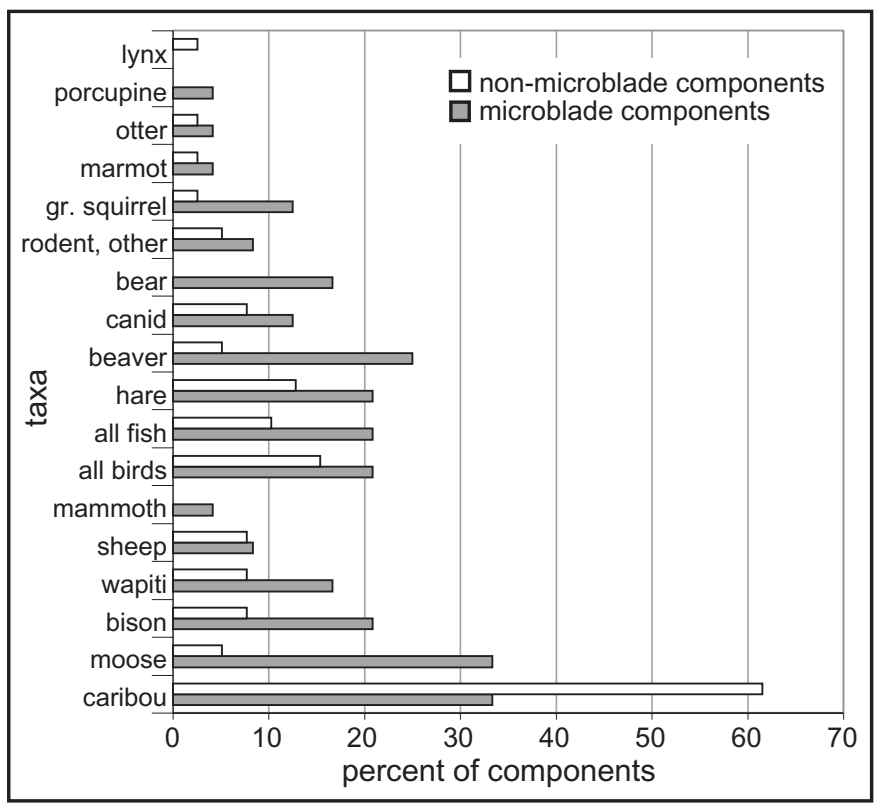

FIG. 5. Association of microblade-bearing components with faunal taxa (DB2 components dated earlier than $1000 \mathrm{cal} \mathrm{BP}$ with identifiable fauna, $\mathrm{n}=63$ ).

and competitive, while the third may have occurred in conjunction with one of the other two, or alone.

\section{Technological and Economic Change Model}

The technological and economic change (TEC) model takes the form of several integrated changes in technology, subsistence, and settlement strategies that may have occurred during the period 1300-800 cal BP. This model posits that before $1300 \mathrm{cal} \mathrm{BP}$, an ancient conservative tradition of multi-seasonal hunting for large mammals, especially bison and wapiti, involved two weapon systems: (1) bifacial projectile points set at the tips of darts thrown with atlatls, used for distance penetration, and (2) composite points made from organic points and microblade side insets set at the tips of hand-held spears, used to dispatch larger, wounded animals. An alternative configuration has

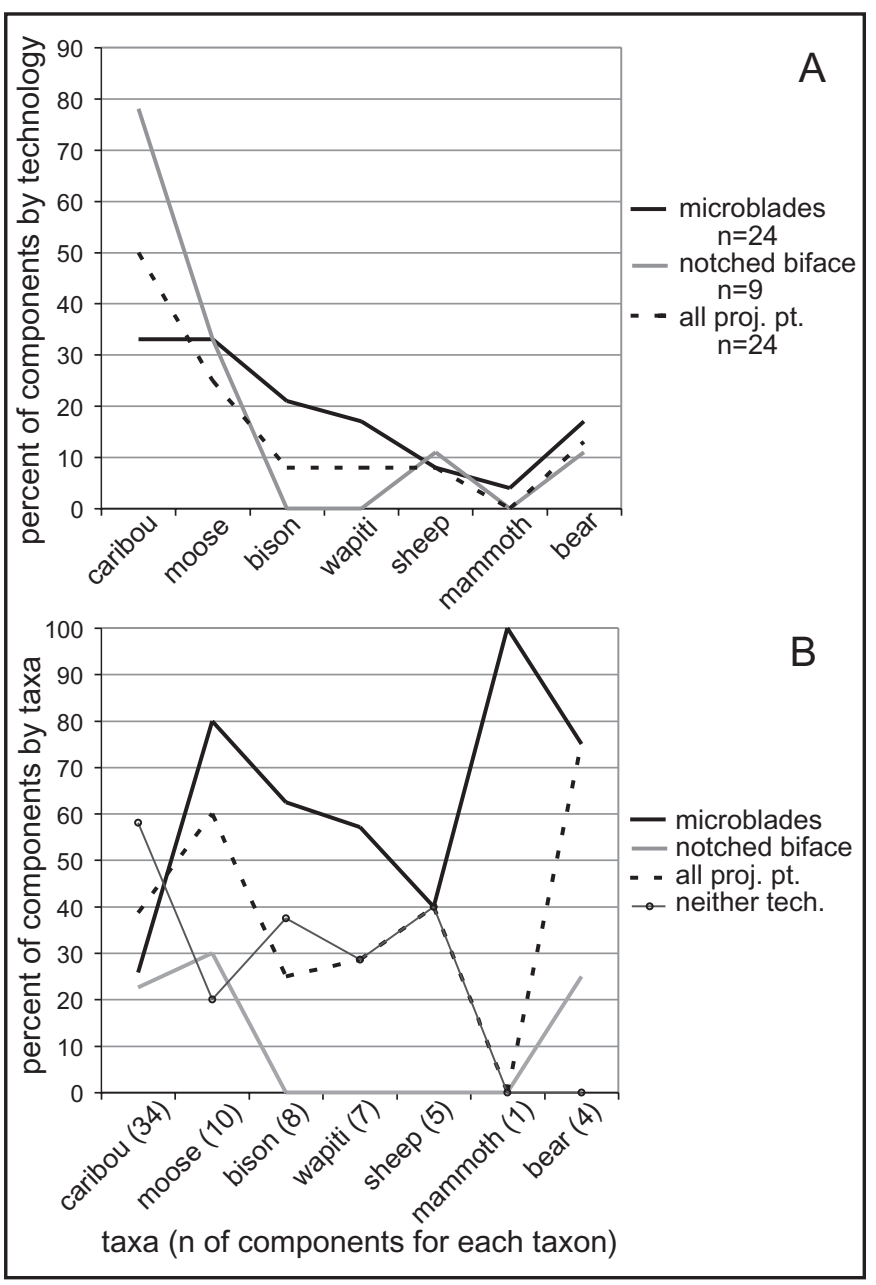

FIG. 6. Relationship of technology and taxa. (A) Associated taxa and components (grouped by technology); (B) associated technology and components (grouped by taxon). Data consist of DB2 components dated earlier than $1000 \mathrm{cal}$ BP associated with identifiable fauna. "Neither" refers to assemblages without projectile points, notched bifaces, or microblades. Percentages in B total more than $100 \%$ because of overlap in technologies and multiple species per component.

these two weapon systems used within different hunting strategies: encounter or pursuit hunting with bifacial dart points and disadvantage hunting with both systems. A third alternative has two atlatl weapon systems used against different-sized prey.

After 1300 cal BP, bow and arrow technology was introduced into the region and incorporated into the already existing hunting strategies, and bows and arrows rapidly replaced atlatls as long-distance weapons. Typical projectile point forms changed from larger lanceolate and notched forms to (1) unilaterally barbed antler arrowheads, (2) smaller stemmed and tanged forms, including the Kavik type, interpreted to function as arrowheads (Workman, 1978), and (3) copper points. This efficient technology allowed for ever-increasing numbers of large game to be hunted, particularly bison. This overhunting, coupled with climate change that reduced grassland bison habitat in the Late Holocene, led to the extirpation of bison in the region. 
With bison populations below a threshold that permitted multiseasonal hunting, populations in the region shifted to a broader-spectrum diet, focused more on seasonally abundant resources like caribou and fish. This shift resulted in the need for increased storage facilities and logistical mobility geared to those seasonally overabundant resources. Increased reliance on fish especially led to a shift in settlement strategies, with longer-term habitations near rich fish streams and lakes, usually in low-lying areas, distant from high-quality tool stone. The resultant reduced residential mobility necessitated a shift in raw material use, from high-quality lithics suitable for flaking to increased use of locally available organic and lower-quality stone implements, and later copper (antler, bone, birch bark, ground and pecked stone, and tci-thos). Microblade technology was phased out because of (1) changes in settlement locations, mobility, and raw material procurement strategies and (2) extirpation of large-bodied bison. This transformation took place within a few hundred calendar years, between 1300 and $800 \mathrm{cal} \mathrm{BP}$.

Holmes and Bacon (1982) hypothesized a link between microblades and bison, but provided little supporting data other than the late bison tibia at site XMH-297 and the continuity of microblade technology during the Holocene. This paper has added substantial data to this question. Microblades are demonstrated to be strongly associated with fauna, suggesting they form part of a hunting toolkit. Specifically, microblades are associated with bison, wapiti, moose, and mammoth, all large and arguably dangerous when wounded. While Guthrie (1983b) argues that the correspondence of microblade technology and caribou geographic distributions may reflect prey-specific use of microblades, this argument runs counter to the empirical patterns identified in this paper. First, caribou as elements in archaeological food assemblages (and ice patch sites) are more closely linked with bifacial points than with microblade/composite points. Second, a wide range of prey is associated with microblade technology, especially large ungulates (bison, moose, and wapiti). Recent reconstructions of wood bison distributions in northwestern North America demonstrate a closer fit with Holocene microblade technology, especially as neither wood bison nor microblade distributions extend much beyond Alberta to the east or south of central British Columbia (Gates et al., 2001; Stephenson et al., 2001).

The proposition that many microblades were used as side insets for weapon tips is supported by a variety of data. Many researchers hypothesize that microblades in Beringia were primarily or exclusively used as side insets into composite organic armatures presumed to function as projectile tips (Larsen, 1968; Guthrie, 1983b; Hare et al., 2004). Other functions, such as knives or daggers (Abramova, 1979; Giria and Pitul'ko, 1994; Derev'anko and Markin, 1998), spear points (Giria and Pitul'ko, 1994), arrow points (Ackerman, 1996; Dixon, 1999), gravers or awls (Sanger, 1968; Ackerman, 1985), and/or saws or shredders (Yi and Clark, 1985), have also been suggested. Microblade morphology and typical retouch locations suggest suitability for cutting, slicing, or penetrating relatively soft materials in a motion parallel to the long axis (Potter, 2005). The shapes of slotted implements vary, but all East Beringian examples are elongate and relatively thin, efficient for multiple piercing (Potter, 2005). As noted above, ice patch data clearly demonstrate a preference for large bifacial points as dart tips throughout the Holocene, suggesting other function(s) for composite implements. One hypothesis is that composite points were used as thrusting spears in disadvantage-hunting strategies against large ungulates, perhaps in conjunction with bifacial point-tipped atlatl darts, whereas the latter were also used in encounter or pursuit hunting of smaller game. An alternative hypothesis, that composite points functioned as atlatl dart tips for use on specific game (large ungulates), is not supported by the data presented here (see below).

Since bifacial projectile points co-occur with microblade technology (especially from $3500-1000$ cal BP, see Fig. 2), there must be some difference that would necessitate two coterminous types of weapon systems, and ice patch data suggest composite points and bifacial points were not simultaneously used as projectile point (dart) tips. One alternative hypothesis is that both systems reflect differential access to lithic raw materials or seasonality, or both. Microblades have been viewed as an efficient technique that conserves lithic raw material by maximizing the working edges produced per unit stone (Sheets and Muto, 1972; see discussion in Yesner and Pearson, 2002). To test this hypothesis, I examined microblade and non-microblade sites found within $5 \mathrm{~km}$ of three known lithic material sources in Interior Alaska (see Potter, 2005). The percentage of microblade sites within $5 \mathrm{~km}$ of lithic raw material sources is $43 \%$ for Batza Téna (Clark and Clark, 1993), 17\% for Livengood (Derry, 1976), and 1\% for Landmark Gap (West, 1981). The last area has relatively few microblade sites, about $3 \%$ of the total, and reflects the relative lack of microblade components in upland areas. The overall percentage of sites with microblade technology in the present sample is $46 \%$ for DB1, and $30 \%$ for DB2, suggesting that microblade sites are not less likely to be found near lithic quarries. In addition, most microblades are unretouched waste discarded at the point of detachment, hardly indicative of tool stone conservation. While these are relatively weak tests, they do not suggest a correlation between limited access to highquality tool stone and microblade technology that might be reflected in differential seasonal use of these technologies. I argue that differential function of bifacial and composite points (whether atlatl vs. thrusting spear tips or prey-specific weapon tips) is the most parsimonious explanation of the co-occurrence of these technologies.

The proposed shift of hunting strategies from the atlatl/ dart system to the bow and arrow system is well documented from recent ice patch archaeology (Hare et al., 2004; see also Dixon et al., 2005). Ethnographically, Interior Alaskan Athabascans used primarily organic technology to manufacture bows and arrows, and points were typically bone, antler, or copper (Shinkwin, 1979; O'Brien, 1997). A number 
of studies have examined relationships of weapons platforms with prey choice and hunting techniques (Odell and Cowan, 1986; Churchill, 2002). Churchill (2002) notes from ethnographic data that hand-held spears are predominantly used with disadvantage techniques to kill larger prey, arrows are used for all hunting techniques and a wide range of prey sizes, and atlatl darts are associated with ambush techniques and smaller prey, though his atlatl data were limited to Australia. These patterns support thrusting spear use for large-bodied prey and the suitability of arrows for most of the resources within the study area.

There is limited evidence of bison and to a lesser extent wapiti habitat disruption in the Late Holocene (Stephenson et al., 2001; Potter, 2005). The Early Holocene boreal forest ( 9000-5500 cal BP) was likely a gallery forest dominated by white spruce and paper birch ( $\mathrm{Hu}$ and Brubaker, 1996). Black spruce replaced white spruce as the dominant tree species by $4000 \mathrm{cal} \mathrm{BP}$. The modern fire regime that followed after $2400 \mathrm{cal} \mathrm{BP}$ was due to the expansion of water-saturated soils that favored black spruce (Hu and Brubaker, 1996; see also Hu et al., 1993; Bigelow, 1997). It is difficult to fit grazing habitats into this record, but Stephenson et al. (2001) note that the geographic distribution of wood bison and Native oral accounts indicate low-elevation habitats, associated with meadows, that persisted in some areas until modern times. Extant wood bison habitats are typically in low-elevation areas within mosaics of meadows and boreal forests (Larter and Gates, 1991; see also discussion in Stephenson et al., 2001), though there is some evidence of summer use of upland areas (Farnell et al., 2004).

Are microblades differentially associated with these lowland habitats? All DB2 components dated earlier than 1000 cal BP were assigned values of "upland" at sites within the foothills of the Alaska Range ( $\mathrm{n}=128)$, primarily in the Upper Susitna, Upper Nenana, and Tangle Lakes areas, and "lowland" at other sites in the study area ( $\mathrm{n}=$ 99), primarily in the bottomlands and lowlands of the Tanana and Copper River basins. Microblade-bearing components are more associated with lowland settings (chisquare $=3.77, p=0.052$ ). Notched biface sites were equally likely to be in upland or lowland settings (chisquare $=0.04, p=0.560$ ). However, caribou strongly associate with upland areas (chi-square $=21.63, p<$ 0.0001 ), whereas $75 \%$ of components with bison are found in lowland areas (80\% if Swan Point CZ3 and Campus contain associated bison; Fisher Exact test, $p=0.061$ ). These patterns reinforce a microblade-bison-lowlands link.

The timing of bison extirpation is unclear. While the latest bison specimen dates to $200 \mathrm{cal} \mathrm{BP}$, Stephenson et al. (2001) note that the critical point is the time when bison populations could no longer be a stable, dependable resource. I argue that this point occurred around $1000 \mathrm{cal} \mathrm{BP}$. The date list from Stephenson et al. (2001) indicates 13 bison specimens from 3000 to $1000 \mathrm{cal} \mathrm{BP}$ in Alaska and Yukon Territory, while only two specimens were dated after 1000 cal BP. Stephenson et al. (2001) note reliance on archery among ethnographically documented Athabascans to kill large mammals like moose and grizzly bears and suggest that bows and arrows were also used to kill bison in the Late Holocene. They further argue that bison habitat was fragmented into ever-diminishing and discontinuous grasslands, and this fragmentation increased their vulnerability to overkill, possibly caused by the juxtaposition of human and bison habitats (Stephenson et al., 2001). The TEC model provides a mechanism for the transition from dispersed multiseasonal hunting in uplands and lowlands to increasingly stable settlements in lowland ecosystems near fish streams and lakes. This change destabilized the previous resilient subsistence system. The introduction of bow and arrow technology could have further accelerated the extirpation of bison in this region between 1300 and 800 cal BP.

Tentative support for this model also comes from studies of salmon abundance variability over the last 2200 years at Kodiak Island, where Finney et al. (2002) showed a decline in Alaskan sockeye salmon populations from 2100 to $1200 \mathrm{cal} \mathrm{BP}$, and an increase in abundance from 800 to $100 \mathrm{cal} \mathrm{BP}$. This increase may have strengthened the importance of salmon fishing after bison populations were decimated.

While the TEC model is generally consistent with a wide variety of empirical data, there are some counterindications. Microblade technology is widespread in space and time, from southern China and Tibet to British Columbia, from $\sim 25,000$ years ago to the recent period, and there is probably considerable variation in microblade use. Various functional considerations may include warfare vs. subsistence, ceremonial vs. functional, non-ungulate preyspecific (perhaps fishing or fowling), and so forth-far too many to test with the limited current data. Microblades seem to be associated with other taxa besides large-bodied ungulates, though this link may relate to the lowland (especially lakeshore) association mentioned above. The tool stone conservation hypothesis cannot be totally discounted given the limited testing described above. More productive tests would involve establishing contemporaneity among a series of sites and controlling for the presence and use of a specific raw material and the distance to the source. The single known slotted dart point found at the Gladstone Ice Patch may indicate the use of microblades for dart tips as well as (or instead of) thrusting spear tips. One could argue that technological and typological variability resolution is too coarse for this time period, and more research needs to be done (including refitting and use-wear studies) to test these interrelated hypotheses fully. Other counter-indications could certainly be put forward.

\section{Population Replacement Model}

The population replacement/assimilation (PRA) model posits that the observed empirical changes in settlement and technology were due to the entry of a new population 
into the study area and its replacement or cultural assimilation (or both) of existing populations. In this model, microblades are associated with earlier populations that are replaced (or assimilated) by later, non-microblade using populations. One might argue that the cultural changes around $1000 \mathrm{cal} \mathrm{BP}$ were too profound for continuity in cultural traditions and populations, and a number of authors have discussed possible migration scenarios. The most influential scenario is from Workman (1972), who suggested that volcanic eruptions that spread ash across the southern Yukon Territory may have influenced Athabascan expansions. Derry (1975) describes a detailed model of partial replacement, in which Athabascans, with an associated toolkit including Kavik-type points but lacking microblade technology, expanded from southwest Yukon to the north and then east across the Brooks Range in response to the volcanic eruption that deposited the eastern lobe of the White River Ash (dated to $1147 \mathrm{cal} \mathrm{BP}$, Clague et al., 1995). Derry associates this group with the proto-Gwich'in. Populations in most of the study area remained in place. In support of this model, microblade technology appears to have disappeared earlier in the southwest Yukon Territory (from $5800 \mathrm{cal} \mathrm{BP}$, the beginning of the Northern Archaic Tradition, Taye Lake Phase) (Workman, 1978), and Kavik points can be characterized as a horizon marker (widespread in space, limited in time). Holmes (1986) suggests that the discontinuity between the Minchumina Tradition and subsequent Spruce Gum Phase (Athabascan) was due to a gap in occupation or population replacement (Holmes, 1977).

Counter-indications to the PRA model include evidence for other volcanic events with widespread tephras that do not correlate with major technological or subsistence changes, such as the northern lobe of the White River Ash, deposited around 1887 cal BP (Leberkmo et al., 1975), or more limited ashfalls in the Susitna basin (e.g., Oshetna and Devil tephras, Dixon et al., 1985). Second, there is no clear break in occupations; the demographic model presented above indicates continual increase in populations (as inferred from component abundance), though this trend might be affected by taphonomic factors. Third, long cultural sequences with no major technological breaks are evident from the nearby southwest Yukon Territory (Workman, 1978) and at Healy Lake (Cook, 1969), suggesting continuity in populations. Finally, Kavik points have been found in a much wider area, including Dixthada and Healy Lake Village in the Tanana Basin.

\section{Taphonomic Bias Model}

The taphonomic bias (TB) model posits that postdepositional disturbance processes caused many of the intersite variability patterns identified above. The absence of cultural depressions before $\sim 1000$ cal BP may be due to erosional or depositional processes that have removed evidence of them (e.g., destroyed them through braided stream development) or covered them to the point that they are no longer archaeologically visible. This model makes no predictions about technological or subsistence systems, other than that organic artifacts are under-represented for earlier time periods. Support for this model includes the presence of semi-subterranean houses at Ushki-1 and the similarity of Dyuktai Culture and Late Pleistocene/ Holocene microblade-bearing traditions (Beringian, Denali, American Paleoarctic). Since the technology, the hypercontinental climate, and the resource base and inferred hunting strategies were relatively similar (microblades and bifacial points associated with large terrestrial mammals), we might expect the habitation structures and settlement strategies to be similar. Other support may include the similar broad-spectrum resource base that continued broadly until recent times (with the exception of bison, wapiti, and mammoth), acquired through logistical and residential mobility, which may have included storage and longer-term habitation facilities. Finally, survey in this region is still very limited (see Potter et al., 2001), and the small sample surveyed thus far may not reflect the underlying variability of site types.

Counter-indications to the TB model include the ethnographically documented preference of Athabascans in the study area for locating longer-term habitations near lakes and clearwater streams rather than on larger, more geologically active glacier-fed braided rivers in the Tanana, Copper, and Yukon basins (Rainey, 1939; Hosley, 1977). Hosley $(1977: 127)$ notes that introduction of the rifle and the European fish wheel, increasing importance of the fur trade, and location of trading posts and missions all acted to decrease the importance of hunting and increase the importance of fishing, which ultimately "contributed to centripetal clustering of Athabascans into permanent settlements along main rivers." Many surveys have been conducted in areas where habitation sites may be located (e.g., along lakeshores) in areas of relatively little erosion or disturbance; however, no evidence of earlier structures has been found. Most importantly, the TB model has no bearing on explaining the transformation in lithic technology, raw material use, and advances in projectile weapons during this period.

\section{DISCUSSION}

This paper identifies and quantifies several important patterns in technology, site structure, and subsistence in the Holocene for this study area. While the data are coarsegrained and are pushed to the limit of their resolution, I have tried to ameliorate this by using broad temporal periods and broad variables (e.g., presence/absence of taxa rather than NISP [number of identified specimens] or MAU [minimum number of anatomical units], which are not available for many of these sites). Three broad classes of models are developed to explain these empirical generalizations, not in normative cultural terms, but rather as historical scenarios that integrate relationships among 
technology, subsistence, and settlement. The TEC model, I believe, is most strongly supported by current data, but aspects of the PRA and TB models are also consistent with some of the data.

Expectations with respect to predicted associations of technology, faunal remains, and habitat/site location can clearly be derived from each of these models. The empirical linkages are clearly described, in order for more productive testing with new site-based and intersite investigations. Future tests and discoveries can clearly confirm or falsify elements of each of the models. These models, and any competing scenarios, must explain observed associations of microblades with fauna (especially large-bodied ungulates), spatial and temporal distribution of microblade-bearing sites with respect to local ecology, co-occurrence of composite and bifacial points, major technological changes observed from ice patch data, very recent evidence of longer-term habitation and storage facilities, the loss of microblades at around $\sim 1000 \mathrm{cal} \mathrm{BP}$, and the reduction of flaked stone toolkits in favor of organic implements.

This study has yielded some intriguing patterns with respect to boreal forest hunter-gatherer mobility and settlement strategies. Two types of sites seem to be represented in the earlier periods (pre $\sim 1000$ cal BP): stations and camps in overlook settings and lower-elevation sites associated with water bodies, especially lakeshores. Some aspects of interassemblage variability seem to relate to these two settings; the latter is associated with higher frequency and diversity of faunal remains and microblade technology, which may be related to resource availability and seasonality. Detailed explorations of lakeshore sites (like Healy Lake and Lake Minchumina) may provide avenues to test some expectations for sites used as residential base camps.

What do these patterns mean with respect to cultural historical sequences? How far back can we "identify" Athabascan or Na-Dene ancestors? As this study does not rely on typological analysis, it has limited utility for defining typological constructs, but it can shed some illumination on the problem. The key difference between Northern Archaic and Late Denali is the presence or absence of microblades (Dixon, 1985). Since microblades are found throughout the Holocene (with a variety of core forms), it is reasonable to posit a regional variety of the Northern Archaic Tradition from $~ 5800$ to 1000 cal BP, characterized by high residential mobility and an economy based on large ungulates, with decreasing importance of bison and increasing importance of caribou, small mammals, birds, and fish. The idea of a "pure" Northern Archaic, without microblades, sometimes termed Palisades Complex and a "mixed" Northern Archaic, with microblades, termed Tuktu Complex (Bacon, 1977; Clark, 1994; Ackerman, 2004) cannot be supported on the basis of these data. While it is possible that all components with notched bifaces and microblades are mixed, this conclusion hardly seems justifiable, since both technologies co-occur in securely dated contexts in this region throughout the last 5800 years.

After $\sim 1000$ cal BP, an Athabascan Tradition characterized by decreasing flaked stone tool use and increasing organic and copper use can be linked with logistical mobility strategies and reliance on seasonally overabundant resources (caribou, salmon, other fish), as well as small mammals and birds. This subsistence strategy and seasonal reliance on storage facilities allowed for increased local band size and sedentism.

While there is still some ambiguity, I suspect that the recent time frame of the transition between these cultural traditions indicates a continuity of Athabascan populations from at least the beginning of the Northern Archaic Tradition. This is consistent with Workman's perspective on the Southwest Yukon Territory record, with a continuity of population from $\sim 5800-5100$ cal BP to the historic period, also associated with the beginning of the Northern Archaic Tradition (Taye Lake Phase) (Workman, 1978).

Speculating on ethnic or linguistic affiliation with earlier periods is much more difficult. The introduction or innovation of new tools (notched bifaces, tabular microblade cores, notched cobbles) at $\sim 5800 \mathrm{cal} \mathrm{BP}$ and the continuation of existing tools (wedge-shaped microblade cores) could be explained by the migration and borrowing of new populations, by partial or total population replacement (Workman, 1978; Dumond, 1987), or by diffusion of a limited number of new artifact types and technologies within extant populations (Clark, 1994). With relatively few excavated components between 9000 and $5000 \mathrm{cal} \mathrm{BP}$, it is difficult to test these hypotheses. Archaeologists have yet to fully integrate the presence of microblade-bearing Swan Point CZ4 prior to Nenana Complex components and the association of Chindadn points and microblades at Swan Point CZ3 (Holmes, 2001), Broken Mammoth CZ3 (Krasinski, 2005), and likely at Healy Lake (Cook, 1969). The synthesis and explanative models developed here represent frameworks through which to explore cultural change over the Holocene. Their use to examine multiple lines of evidence will aid in building a firm foundation on which to situate future hypothesis testing and excavation.

\section{ACKNOWLEDGEMENTS}

A synthetic analysis such as this is possible only through the efforts of numerous researchers in Interior Alaska, and I thank them collectively. Joshua Reuther, Chuck Holmes, John Cook, Bill Workman, Peter Bowers, Tom Gillispie, Craig Gerlach, and others provided valuable comments on earlier iterations of this research. Two anonymous reviewers provided thoughtful feedback and useful suggestions for increased clarity within this detailed synthesis. This work was funded in part by a Wenner-Gren Hunt Post-doctoral Fellowship. 


\section{APPENDIX: DATABASE REFERENCES}

TABLE A1. All DB2 sites, ordered by reference. ${ }^{1}$

\begin{tabular}{|c|c|}
\hline Sites & Reference \\
\hline XBD-110, XMH-297 & Bacon and Holmes, 1980 \\
\hline HEA-189 & Betts, 1987 \\
\hline HEA-031 & Bowers, 1980 \\
\hline HEA-295 & Bowers et al., 1995 \\
\hline GUL-076 & Clark, 1974 \\
\hline XMH-204, XBD-020 & Cook, 1969, 1996 \\
\hline XMH-227 & Cook et al., 1977 \\
\hline FAI-045 & Dixon et al., 1980 \\
\hline $\begin{array}{l}\text { TLM-016-18, 21B, 22, 27, 30, 34, } \\
38-40,43,46,48,50,55,59, \\
61-64 B, 69,73,77,88,96-97, \\
102,115,119,126,128,130, \\
142-143,149-151,159-160, \\
164-165,169,171,173-175,180, \\
182,184,191-192,194,199,202, \\
206,207,213,215,216,217,220, \\
225,229-230,241,250,253\end{array}$ & Dixon et al., 1985 \\
\hline XMH-384, 602 & Gillispie, 1992 \\
\hline HEA-130 & Goebel et al., 1996 \\
\hline XBD-167, 183, XMH-838-839 & Higgs et al., 1999; Potter et al., 2007c \\
\hline HEA-038 & Hoffecker and Powers, 1996 \\
\hline HEA-128 & Hoffecker, 1985 \\
\hline MMK-004, 007, 012 & Holmes, 1986 \\
\hline HEA-239 & Holmes, 1988 \\
\hline XBD-131 & $\begin{array}{l}\text { Holmes, 1996; } \\
\text { Yesner and Pearson, 2002; } \\
\text { Krasinski, } 2005\end{array}$ \\
\hline XBD-156 & Holmes et al., 1996 \\
\hline XBD-071 & Dilley, 1998 \\
\hline FAI-035 & Maitland, 1986; Lively, 1996 \\
\hline XMH-239 & McKay, 1981 \\
\hline FAI-001 & $\begin{array}{l}\text { Mobley, 1991; } \\
\quad \text { Pearson and Powers, } 2001\end{array}$ \\
\hline ХМH-035, 289 & Mobley, 1982 \\
\hline FAI-206 & Pearson, 1999 \\
\hline FAI-091 & Phippen, 1988 \\
\hline HEA-062 & Plaskett, 1977 \\
\hline FAI-1661 & Potter, 2004b \\
\hline XMH-246 & Potter, 2005 \\
\hline TNX-078-079, 088-089 & Potter et al., 2002 \\
\hline XBD-281-328 & Potter et al., 2007a \\
\hline XBD-335-343 & Potter et al., 2007b \\
\hline HEA-005 & Powers et al., 1983 \\
\hline HEA-137 & Powers and Maxwell, 1986 \\
\hline NAB-003 & Rainey, 1939 \\
\hline ANC-017 & Reger and Bacon, 1996 \\
\hline VAL-206, 215 & Reger, 1985 \\
\hline VAL-068 & Reger et al., 1975 \\
\hline XMH-252 & Reger et al., 1964 \\
\hline HEA-327 & Reuther et al., 2003 \\
\hline TNX-033 & $\begin{array}{l}\text { Gerlach et al., 1989; } \\
\quad \text { Sheppard et al., } 1991\end{array}$ \\
\hline TNX-004 & Shinkwin, 1979 \\
\hline GUL-100 & U.S. Bureau of Indian Affairs, 1986 \\
\hline XBD-163 & Vanderhoek et al., 1997 \\
\hline MMK-005 & West, 1978 \\
\hline HEA-001 & West, $1996 b$ \\
\hline XMH-072 & West et al., 1996b \\
\hline XMH-111 & West et al., 1996a \\
\hline XMH-149 & West et al., 1996c \\
\hline XMH-005 & West, 1967, 1981 \\
\hline XMH-130, 166, 177 & West, 1972 \\
\hline GUL-077 & Workman, 1976 \\
\hline
\end{tabular}

${ }^{1}$ Table A1 lists the sites and primary references included in this synthesis. Site prefixes refer to USGS 250000 scale quadrangles (ANC-Anchorage, FAI-Fairbanks, HEA-Healy, GUL-Gulkana,
NAB-Nabesna, TLM-Talkeetna Mountains, VAL-Valdez, XBDBig Delta, XMH-Mount Hayes). Component dating generally follows the original investigator, except that Healy Lake Athabascan Stage Levels 1-3 (Cook, 1969) are grouped into two components, Level 1 (962-675 cal BP) and Levels 2-3 (33422952 cal BP). Late Holocene dates at Donnelly Ridge (West, 1967) and Little Panguingue Creek (Hoffecker and Powers, 1996) are tentatively accepted, given no convincing demonstration of contamination.

\section{REFERENCES}

ABRAMOVA,Z.A. 1979. Paleolit Yeniseya: Kokorevskaya kul'tura [Paleolithic of the Yenisey: The Kokorevo culture]. Novosibirsk: Nauka.

ACKERMAN, R.E. 1985. Southwestern Alaska archeological survey. National Geographic Society Research Reports 19: 67-94.

_ 1996. Cave 1, Lime Hills. In: West, F.H., ed. American beginnings. Chicago: University of Chicago Press. 470-477.

- 2004. The Northern Archaic Tradition in southwestern Alaska. Arctic Anthropology 41(2):153-162.

AGER, T.A., and BRUBAKER, L.B. 1985. Quaternary palynology and vegetational history of Alaska. In: Bryant, V.M., and Holloway, R.G., eds. Records of Late Quaternary North American sediments. Dallas: American Association of Stratigraphic Palynologists. 353-384.

ANDERSON, D.D. 1968. A stone age campsite at the gateway to America. Scientific American 218(6):24-33.

- 1988. Onion Portage: The archaeology of a stratified site from the Kobuk River, Northwest Alaska. Anthropological Papers of the University of Alaska 22(1-2).

ANDREFSKY, W., Jr. 1994. Raw-material availability and the organization of technology. American Antiquity 59:21-34.

BACON, G.H. 1977. The prehistory of Alaska: A speculative alternative. In: Helmer, J.W., Van Dyke, S., and Kense, F.J., eds. Problems in the prehistory of the North American Subarctic: The Athapaskan question. Calgary: University of Calgary Archaeological Association. 1-10.

1987. A cultural chronology for central Interior Alaska: A critical appraisal. Quarterly Review of Archaeology (June 1987):3-5.

BACON, G.H., and HOLMES, C.E. 1980. Archaeological survey and inventory of cultural resources at Fort Greely, Alaska, 1979. ALASKARCTIC. Report submitted to the U.S. Army Corps of Engineers, Alaska District, Contract No. DAC85-78-C-0045. On file at the Office of History and Archaeology, 550 West 7th Avenue, Suite 1310, Anchorage, Alaska 99501.

BAMFORTH, D.B. 1986. Technological efficiency and tool curation. American Antiquity 43(1):38 - 50.

- 1991. Technological organization and hunter-gatherer land use: A California example. American Antiquity 56(2): 216-234.

BETTS, R.C. 1987. Archaeological investigations at Butte Lake, Alaska: A report to the University of Alaska Museum Geist Fund. Report on file at the Alaska Office of History and 
Archaeology, 550 West 7th Avenue, Suite 1310, Anchorage, Alaska 99501.

BEVER, M.R. 2001. An overview of Alaskan Late Pleistocene archaeology: Historical themes and current perspectives. Journal of World Prehistory 15:125-191.

BIGELOW, N.H. 1997. Late Quaternary vegetation and lake level changes in central Alaska. PhD dissertation, Department of Anthropology, University of Alaska Fairbanks, Fairbanks.

BINFORD, L.R. 1973. Interassemblage variability: The Mousterian and the "functional" argument. In: Renfrew, C., ed. The explanations of culture change: Models in prehistory. London: Duckworth. 227-253.

1979. Organization and formation processes: Looking at curated technologies. Journal of Anthropological Research 35:255-273.

- 1980. Willow smoke and dogs' tails: Hunter-gatherer settlement systems and archaeological site formation. American Antiquity 45(1):4-20.

- 1983. Working at archaeology. New York: Academic Press. BOWERS, P.M. 1980. The Carlo Creek site: Geology and archaeology of an early Holocene site in the central Alaska Range. Fairbanks: Anthropology and Historic Preservation Cooperative Park Studies Unit, University of Alaska.

. 1999. AMS dating of the Area 22 American PaleoArctic Tradition microblade component at the Lisburne Site, Arctic Alaska. Current Research in the Pleistocene 16:12-14.

BOWERS, P.M., MASON, O.K., LUDWIG, S.L., HIGGS, A.S., and SMYTHE, C.W. 1995. Cultural resources inventory and assessment of the proposed Healy to Fairbanks Northern Intertie, South Route and Tanana Flats Alternatives. Report submitted to Golden Valley Electric Association, Fairbanks. NLUR Technical Report No. 30. Fairbanks: Northern Land Use Research, Inc.

CARLSON, D. 1979. Hunter-gatherer mobility strategies: An example from the Koster site in the Lower Illinois Valley. PhD dissertation, Northwestern University, Evanston, Illinois.

CHURCHILL, S.E. 2002. Weapon technology, prey size selection, and hunting methods in modern hunter-gatherers: Implications for hunting in the Palaeolithic and Mesolithic. In: Peterkin, G.L., Bricker, H.M., and Mellars, P., eds. Hunting and animal exploitation in the Later Palaeolithic and Mesolithic of Eurasia. Archeological Papers of the American Anthropological Association 4. 11-24.

CLAGUE, J.J., EVANS, S.G., RAMPTON, V.N., and WOODSWORTH, G.J. 1995. Improved age estimates for the White River and Bridge River tephras, western Canada. Canadian Journal of Earth Sciences 32:1172-1179.

CLARK, D.W. 1981. Prehistory of the Western Subarctic. In: Helm, J., ed. Handbook of North American Indians, Vol. 6, Subarctic. Washington D.C.: Smithsonian Institution Press. $107-129$.

- 1994. The Archaic in the extreme northwest of North America. Revista de Arqueología Americana 5:71-99.

- 2001. Microblade-culture systematics in the far Interior Northwest. Arctic Anthropology 38(2):64-80.

CLARK, D.W., and CLARK, A.M. 1993. Batza Tena: Trail to obsidian. Mercury Series, Archaeological Survey of Canada Paper No. 147. Hull, Quebec: Canadian Museum of Civilization.
CLARK, G.H. 1974. Archaeological survey and excavation along the southernmost portion of the Trans-Alaska Pipeline System. Final Report to the Alyeska Pipeline Service Company. Report on file at the Alaska Office of History and Archaeology, 550 West 7th Avenue, Suite 1310, Anchorage, Alaska 99501.

COOK, J.P. 1969. The early prehistory of Healy Lake, Alaska. PhD dissertation, University of Wisconsin, Madison, Wisconsin.

- 1989. Historic archaeology and ethnohistory at Healy Lake, Alaska. Arctic 42(2):109-118.

. 1996. Healy Lake. In: West, F.H., ed. American beginnings. Chicago: University of Chicago Press. 323-327.

COOK, J.P., and GILLISPIE, T.E. 1986. Notched points and microblades. Paper presented at the 13th Annual Meeting of the Alaska Anthropological Association, Fairbanks, Alaska.

COOK, J.P., and McKENNAN, R.A. 1970. The Athapaskan tradition: A view from Healy Lake in the Yukon-Tanana Upland. Paper presented at the 10th Annual Meeting of the Northeastern Anthropological Association, Ottawa, Ontario.

COOK, J.P., NEWELL, R.R., and WIERSUM, W.E. 1977. Hogan's Hill to Salcha River. In: Cook, J.P., ed. Pipeline Archeology: Final Report. Fairbanks: University of Alaska Fairbanks. $70-180$.

DEREV'ANKO, A.P., and MARKIN, S. 1998. The Middle and Upper Paleolithic of Western and Central Siberia. In: Derev' anko, A.P., ed. The Paleolithic of Siberia: New discoveries and interpretations. Urbana: University of Illinois Press. 79-84.

DERRY, D.E. 1975. Later Athapaskan prehistory: A migration hypothesis. Western Canadian Journal of Anthropology 5 (3-4):134-147.

- 1976. Archeological research in the Livengood (Alaska) area. In: Cook, J.P., ed. Analysis of Pipeline Archeology: Progress report. Report to Alyeska Pipeline Service Company. Report on file at the Alaska Office of History and Archaeology, 550 West 7th Avenue, Suite 1310, Anchorage, Alaska 99501.

DIKOV, N.N. 1977. Arkheologicheskie Pamiatniki Kamchatki, Chukotki I Verkhnei Kolmy [Archaeological sites of Kamchatka, Chukotka, and the Upper Kolyma]. Moscow: Nauka.

DILLEY, T.E. 1998. Late Quaternary loess stratigraphy, soils, and environments of the Shaw Creek Flats Paleoindian sites, Tanana Valley, Alaska. PhD dissertation, University of Arizona, Tucson, Arizona.

DIXON, E.J., Jr. 1985. Cultural chronology of central Interior Alaska. Arctic Anthropology 22(1):47-66.

. 1999. Bones, boats, and bison: Archeology and the first colonization of western North America. Albuquerque: University of New Mexico Press.

DIXON, E.J., Jr., SMITH, G.S., and PLASKETT, D. 1980. Archaeological survey and inventory of cultural resources, Fort Wainwright, Alaska. Prepared for U.S. Army Corps of Engineers, Alaska District. On file at the Office of History and Archaeology, 550 West 7th Avenue, Suite 1310, Anchorage, Alaska 99501.

DIXON, E.J., Jr., SMITH, G.S., ANDREFSKY, W., Jr., SALEEBY, B., and UTERMOHLE, C. 1985. Susitna hydroelectric project cultural resource investigations: 1979-1985. Report prepared for the Alaska Power Authority. On file at the Office of History and Archaeology, 550 West 7th Avenue, Suite 1310, Anchorage, Alaska 99501. 
DIXON, E.J., Jr., MANLEY, W.F., and LEE, C.M. 2005. The emerging archaeology of glaciers and ice patches: Examples from Alaska's Wrangell-St. Elias National Park and Preserve. American Antiquity 70(1):129-143.

DUMOND, D.E. 1987. The Eskimos and Aleuts, rev. ed. London: Thames and Hudson.

FARNELL, R.P., HARE, P.G., BLAKE, E., BOWYER, V., SCHWEGER, C., GREER, S., and GOTTHARDT, R. 2004. Multidisciplinary investigations of alpine ice patches in southwest Yukon, Canada: Paleoenvironmental and paleobiological investigations. Arctic 57(3):247-259.

FINNEY, B.P., GREGORY-EAVES, I., DOUGLAS, M.S.V., and SMOL, J.P. 2002. Fisheries productivity in the northeastern Pacific Ocean over the past 2000 years. Nature 416:729-733.

GATES, C.C., STEPHENSON, R.O., REYNOLDS, H.W., VAN ZYLL DE JONG, C.G., SCHWANTJE, H., HOEFS, M., NISHI, J., COOL, N., CHISHOLM, J., JAMES, A., and KOONZ, B. 2001. National recovery plan for the wood bison (Bison bison athabascae). National Recovery Plan No. 21. Ottawa: Recovery of Nationally Endangered Wildlife (RENEW).

GERLACH, S.C., STEFFIAN, A.F., VINSON, D.M., JORDAN, J.W., and MOLINA, D.J. 1989. Over-the-horizon backscatter Alaska Radar System. Report of 1989 archaeological investigations of the Tok and Gulkana study areas, Alaska. University of Alaska Museum: Occasional Papers in Archaeology No. 1(1)

GILLISPIE, T.E. 1992. Archaeological data recovery and evaluation, Landmark Gap Trail, Alaska. Fairbanks: Report submitted to the Bureau of Land Management, Glennallen District Office by GDM, Inc.

GIRIA, E.Yu., and PITUL'KO, V.V. 1994. A High Arctic mesolithic industry on Zhokov Island: Inset tools and knapping technology. Arctic Anthropology 31(2):31-44.

GOEBEL, T.E. 1999. Pleistocene human colonization of Siberia and the peopling of the Americas: An ecological approach. Evolutionary Anthropology 8(6):208-227.

GOEBEL, T.E., and POWERS, W.R. 1989. A possible paleoindian dwelling in the Nenana Valley, Alaska: Spatial analysis at the Walker Road site. Paper presented at the 16th Annual Meeting of the Alaska Anthropological Association, Anchorage.

GOEBEL, T.E., and SLOBODIN, S.B. 1999. The colonization of Western Beringia: Technology, ecology, and adaptations. In: Bonnichsen, R., and Turnmire, K.L., eds. Ice age people of North America: Environments, origins, and adaptations. Corvallis: Oregon State University Press. 104-155.

GOEBEL, T.E., POWERS, W.R., BIGELOW, N.H., and HIGGS, A.S. 1996. Walker Road. In: West, F.H., ed. American beginnings. Chicago: University of Chicago Press. 356-363.

GUTHRIE, R.D. 1983a. Appendix B: Composite bone-stone tool reproduction and testing. In: Powers, W.R., Guthrie, R.D., and Hoffecker, J.F., eds. Dry Creek: Archeology and paleoecology of a Late Pleistocene Alaskan hunting camp. Washington, D.C.: National Park Service. 348-374.

- 1983b. Osseous projectile points: Biological considerations affecting raw material selection and design among paleolithic and paleoindian peoples. In: Clutton, J., and Grigson, C., eds. Animals and archaeology: Hunters and their prey. BAR
International Series 163. London: British Archaeological Reports. 273-294.

HAMILTON, T.D., and GOEBEL, T.E. 1999. Late Pleistocene peopling of Alaska. In: Bonnichsen, R., and Turnmire, K.L., eds. Ice age people of North America: Environments, origins, and adaptations. Corvallis: Oregon State University Press. $156-199$.

HARE, P.G., GREER, S., GOTTHARDT, R., FARNELL, R., BOWYER, V., SCHWEGER, C., and STRAND, D. 2004. Ethnographic and archaeological investigations of alpine ice patches in southwest Yukon, Canada. Arctic 57(3):260-272.

HIGGS, A.S. 1992. Technological and spatial considerations of the Walker Road site: Implications from a lithic refit study. MA research paper, Department of Anthropology, University of Alaska Fairbanks.

HIGGS, A.S., POTTER, B.A., BOWERS, P.M., and MASON, O.K. 1999. Cultural resource survey of the Yukon Training Area and Fort Greely Army lands withdrawal, Alaska. Report submitted to ABR, Inc. and U.S. Army Cold Regions Research and Engineering Laboratory. NLUR Technical Report No. 66. Fairbanks: Northern Land Use Research, Inc.

HOFFECKER, J.F. 1985. North Alaska Range Early Man Project: Archaeological field research: 1980. In: Swanson, W., ed. On research and exploration projects supported by the National Geographic Society, for which an initial grant or continuing support was provided in the year 1978. National Geographic Society Research Reports 19:48-59.

HOFFECKER, J.F., and POWERS, W.R. 1996. Little Panguingue Creek. In: West, F.H., ed. American beginnings. Chicago: University of Chicago Press. 371-374.

HOLMES, C.E. 1977. 3000 years of prehistory at Minchumina: The question of cultural boundaries. In: Helmer, J.W., Van Dyke, S., and Kense, F.J., eds. Problems in the prehistory of the North American Subarctic: The Athapaskan question. Calgary: University of Calgary Archaeological Association. 11-15.

1986. Lake Minchumina prehistory: An archaeological analysis. Alaska Anthropological Association Monograph Series, Aurora 2.

- 1988. An early post Paleo-Arctic site in the Alaska Range. Paper presented at the 15th Annual Meeting of the Alaska Anthropological Association, Fairbanks.

- 1996. Broken Mammoth. In: West, F.H., ed. American beginnings. Chicago: University of Chicago Press. 312-318.

- 2001. Tanana River Valley archaeology circa 14,000 to 9000 BP. Arctic Anthropology 38(2):154-170.

- 2004. Pre-Clovis traces at Swan Point, Alaska: Early Americans in eastern Beringia. Interview given to Floyd Largent, Jr. Mammoth Trumpet 20(1):4-7.

HOLMES, C.E., and BACON, G.H. 1982. Holocene bison in central Alaska: A possible explanation for technological conservatism. Paper presented at the 9th Annual Meeting of the Alaska Anthropological Association, Fairbanks.

HOLMES, C.E., VANDERHOEK, R., and DILLEY, T.E. 1996. Swan Point. In: West, F.H., ed. American beginnings. Chicago: University of Chicago Press. 319-323.

HOSLEY, E.H. 1977. A reexamination of the salmon dependence of the Pacific drainage culture Athapaskans. In: Helmer, J.W., 
Van Dyke, S., and Kense, F.J., eds. Problems in the prehistory of the North American Subarctic: The Athapaskan question. Calgary: University of Calgary Archaeological Association. $124-129$.

HU, F.S., and BRUBAKER, L.B. 1996. Boreal ecosystem development in the northwestern Alaska Range since 11,000 yr B.P. Quaternary Research 45:188-201.

HU, F.S., BRUBAKER, L.B., and ANDERSON, P.M. 1993. A 12,000 year record of vegetation change and soil development from Wien Lake, Central Alaska. Canadian Journal of Botany 71:1133-1142.

IVES, J.W. 1990. A theory of Northern Athapaskan prehistory. Calgary: University of Calgary Press.

KELLY, R.L., and TODD, L.C. 1988. Coming into the country: Early Paleoindian hunting and mobility. American Antiquity 53:231-244.

KETZ, J.A. 1983. Paxson Lake: Two nineteenth century Ahtna sites in the Copper River basin, Alaska. Occasional Paper 33. Fairbanks: Anthropology and Historic Preservation, Cooperative Park Studies Unit, University of Alaska. 281 p.

KRASINSKI, K.E. 2005. Intrasite spatial analysis of late Pleistocene/ early Holocene archaeological material from the Broken Mammoth site. MA thesis, University of Alaska Anchorage, Anchorage.

KUHN, S.L. 1994. A formal approach to the design and assembly of mobile toolkits. American Antiquity 59:426-442.

LARSEN, H. 1968. Trail Creek: Final report on the excavation of two caves on Seward Peninsula, Alaska. Acta Arctica 15.

LARTER, N.C., and GATES, C.C. 1991. Diet and habitat selection of wood bison in relation to seasonal change in forage quantity and quality. Canadian Journal of Zoology 69:2677-2685.

LEBERKMO, J.F., WESTGATE, J.A., SMITH, D.G.W., and DENTON, G.H. 1975. New data on the character and history of the White River volcanic eruption, Alaska. In: Suggate, R.P., and Creswell, M.M., eds. Quaternary studies. Wellington: Royal Society of New Zealand. 203-209.

LIVELY, R.A. 1996. Chugwater. In: West, F.H., ed. American beginnings. Chicago: University of Chicago Press. 308-311.

MAITLAND, R.E. 1986. The Chugwater site (FAI-035), Moose Creek bluff, Alaska. Final report, 1982 and 1983 seasons. Unpubl. report on file, U.S. Army Corps of Engineers, Alaska District, Anchorage.

MASCHNER, H.D.G. 1989. Site structure and prehistoric land use: An analysis of excavations at VAL-216, a late prehistoric site on Tazlina Lake, Alaska. MA thesis, Department of Anthropology, University of Alaska Fairbanks.

MASON, O.K., BOWERS, P.M., and HOPKINS, D.M. 2001. The early Holocene Milankovitch thermal maximum and humans: Adverse conditions for the Denali complex of eastern Beringia. Quaternary Science Reviews 20:525-548.

McKAY, J.E. 1981. Cultural resources investigations of the Denali Highway project. In: Gibson, D.E., ed. Archaeological survey projects, 1979. Miscellaneous Publications, History and Archaeology Series 28. 201-236.

MOBLEY, C.M. 1982. The Landmark Gap Trail site, Tangle Lakes, Alaska: Another perspective on the Ampitheater Mountain complex. Arctic Anthropology 19(1):81-102.

\section{Press.}

1991. The Campus site. Fairbanks: University of Alaska

MORLAN, R.E. 1973a. The later prehistory of the Middle Porcupine drainage, northern Yukon Territory. Mercury Series, Archaeological Survey of Canada Paper No. 11. Ottawa: National Museum of Man.

. 1973b. A technological approach to lithic artifacts from Yukon Territory. Mercury Series, Archaeological Survey of Canada Paper No. 7. Ottawa: National Museum of Man.

O'BRIEN, T.A. 1997. Athabaskan implements from the skin house days as related by Reverend David Salmon. MA thesis, Department of Anthropology, University of Alaska Fairbanks.

ODELL, G.H. 1988. Addressing prehistoric hunting practices through stone tool analysis. American Anthropologist 90: $335-336$.

- 1996. Economizing behavior and the concept of "curation." In: Odell, G.H., ed. Stone tools: Theoretical insights into human prehistory. New York: Plenum Press. 51-80.

ODELL, G.H., and COWAN, F. 1986. Experiments with spears and arrows on animal targets. Journal of Field Archaeology 13: $195-212$.

OVERPECK, J.T., PETERSON, L.C., KIPP, N., IMBRIE, J., and RIND, D. 1989. Climate change in the circum-North Atlantic region during the last deglaciation. Nature 338:553-557.

PEARSON, G.A. 1999. Early occupations and cultural sequence at Moose Creek: A late Pleistocene site in central Alaska. Arctic 52(4):332-345.

PEARSON, G.A., and POWERS, W.R. 2001. The Campus site reexcavation: New efforts to unravel its ancient and recent past. Arctic Anthropology 38(1):100-119.

PHIPPEN, P.G. 1988. Archaeology at Owl Ridge: A PleistoceneHolocene boundary age site in central Alaska. MA thesis, University of Alaska Fairbanks, Fairbanks.

PLASKETT, D. 1977. The Nenana Gorge site: A late prehistoric Athabaskan campsite in central Alaska. MA thesis, University of Alaska Fairbanks.

POTTER, B.A. 2004a. Modeling intersite variability in Interior Alaska: Overcoming conceptual ambiguity through pattern recognition. Paper presented at the 69th Annual Meeting of the Society for American Archaeology, Montreal.

. 2004b. Cultural resources survey of proposed seismic survey lines near Nenana, Alaska. Prepared for Andex Resources, LLC. NLUR Technical Report No. 253. Fairbanks: Northern Land Use Research, Inc. On file at the Office of History and Archaeology, 550 West 7th Avenue, Suite 1310, Anchorage, Alaska 99501.

. 2005. Site structure and organization in central Alaska: Archaeological investigations at Gerstle River. PhD dissertation, University of Alaska Fairbanks.

__ 2 2008. Radiocarbon chronology of Central Alaska: Technological continuity and economic change. Radiocarbon 50(2): $181-204$.

POTTER, B.A., BOWERS, P.M., WOOLEY, C.B., REUTHER, J.D., FARMEN, K.W.M., and McINTOSH, S.J. 2001. Cultural resources data assessment for the North American Natural Gas Pipeline Project area. Report prepared for BP Exploration, Alaska, Inc., and North American Natural Gas Pipeline Group 
by Northern Land Use Research, Inc., Fairbanks and Chumis Cultural Resources Services, Anchorage. NLUR Technical Report No. 109. On file at the Office of History and Archaeology, 550 West 7th Avenue, Suite 1310, Anchorage, Alaska 99501.

POTTER, B.A., BOWERS, P.M., WOOLEY, C.B., GALLISON, J.D., SHEPPARD, W.L., GELVIN-REYMILLER, C., and REUTHER, J.D. 2002. Results of the 2001 phase I cultural resources survey of the proposed Alaska Gas Pipeline Project area, southern route. Report prepared for Alaska Gas Producers Pipeline Team by Northern Land Use Research, Inc., Fairbanks, and Chumis Cultural Resource Services, Anchorage. NLUR Technical Report No. 147. On file at the Office of History and Archaeology, 550 West 7th Avenue, Suite 1310, Anchorage, Alaska 99501.

POTTER, B.A., GAINES, E.P., BOWERS, P.M., and PROUE, M. 2007a. Results of the 2006 cultural resource survey of proposed Alaska Railroad Northern Rail Extension routes and ancillary facilities, Alaska. Report prepared for ICF International by Northern Land Use Research, Inc., Fairbanks. NLUR Technical Report No. 278b-c. On file at the Office of History and Archaeology, 550 West 7th Avenue, Suite 1310, Anchorage, Alaska 99501.

POTTER, B.A., REUTHER, J.D., BOWERS, P.M., and GELVINREYMILLER, C. 2007b. Results of the 2007 cultural resource survey of proposed Alaska Railroad Northern Rail Extension, Alaska. Report prepared for ICF International by Northern Land Use Research, Inc., Fairbanks. NLUR Technical Report No. 333. On file at the Office of History and Archaeology, 550 West 7th Avenue, Suite 1310, Anchorage, Alaska 99501.

POTTER, B.A., BOWERS, P.M., REUTHER, J.D., and MASON, O.K. 2007c. Holocene assemblage variability in the Tanana Basin: NLUR archaeological research, 1994-2004. Alaska Journal of Archaeology 5(1):23-42.

POWERS, W.R., and MAXWELL, H.E. 1986. Lithic remains from Panguingue Creek, an early Holocene site in the northern foothills of the Alaska Range. Studies in History 189. Anchorage: Alaska Historical Commission.

POWERS, W.R., GUTHRIE, R.D., and HOFFECKER, J.F., eds. 1983. Dry Creek: Archeology and paleoecology of a late Pleistocene Alaskan hunting camp. Washington, D.C.: National Park Service.

RAINEY, F.G. 1939. Archaeology in central Alaska. Anthropological Papers of the American Museum of Natural History 36(4):355-405.

REGER, D.R. 1985. Archaeological survey of the Tazlina Lake area, 1982-83. Report of Investigations 85-9. Anchorage: Alaska Division of Geological and Geophysical Surveys.

REGER, D.R., and BACON, G.H. 1996. Long Lake. In: West, F.H., ed. American beginnings. Chicago: University of Chicago Press. 436-437.

REGER, D.R., COLE, T., and BROWN, C.M. 1975. Report of archaeological and historical investigations along the Copper River, Tasnuna River to Chitina. Miscellaneous Publications, History and Archaeology Series 10.

REGER, R.D., PÉWÉ, T.L., WEST, F.H., and SKARLAND, I. 1964. Geology and archeology of the Yardang Flint Station. Anthropological Papers of the University of Alaska 12(2): 92-100.
REIMER, P.J., BAILLIE, M.G.L., BARD, E., BAYLISS, A., BECK, J.W., BERTRAND, C.J.H., BLACKWELL, P.G., BUCK, C.E., BURR, G.S., CUTLER, K.B., DAMON, P.E., EDWARDS, R.L., FAIRBANKS, R.G., FRIEDRICH, M., GUILDERSON, T.P., HOGG, G., HUGHEN, K.A., KROMER, B., McCORMAC, F.G., MANNING, S., RAMSEY, C.B., REIMER, R.W., REMMELE, S., SOUTHON, J.R., STUIVER, M., TALAMO, S., TAYLOR, F.W., VAN DER PLICHT, J., and WEYHENMEYER, C.E. 2004. IntCal04 terrestrial radiocarbon age calibration, 0-26 cal kyr BP. Radiocarbon 46:1029-1058.

REUTHER, J.D., KRIZ, P.J., POTTER, B.A., and BOWERS, P.M. 2003. Cultural resources survey and evaluation of tunnels and proposed stabilization areas along the Alaska Railroad, Healy Canyon, Alaska. Prepared for Alaska Railroad Corporation and URS Corporation. NLUR Technical Report No. 202. Fairbanks: Northern Land Use Research, Inc.

SANGER, D. 1968. Prepared core and blade traditions in the Pacific Northwest. Arctic Anthropology 5(1):92-120.

SHEETS, P.D., and MUTO, G.R. 1972. Pressure blades and total cutting edge: An experiment in lithic technology. Science 175(4022):632-634.

SHEPPARD, W.L., STEFFIAN, A.F., STALEY, D.P., and BIGELOW, N.H. 1991. Late Holocene occupations at the Terrace site, Tok, Alaska. Report prepared for U.S. Air Force, Electronic Systems Division. Anchorage: Arctic Environmental Information and Data Center, University of Alaska.

SHINKWIN, A.D. 1977. The "archaeological visibility" of Northern Athapaskans in the Tanana River area, central Alaska: A discussion. In: Helmer, J.W., Van Dyke, S., and Kense, F.J., eds. Problems in the prehistory of the North American Subarctic: The Athapaskan question. Calgary: University of Calgary Archaeological Association. 40-45.

. 1979. Dakah De'nin's village and the Dixthada site: A contribution to northern Athapaskan prehistory. Mercury Series, Archaeological Survey of Canada Paper No. 91. Ottawa: National Museum of Man.

SHOTT, M.J. 1986. Technological organization and settlement mobility: An ethnographic examination. Journal of Anthropological Research 42:15-51.

SLOBODIN, S. 2001. Western Beringia at the end of the ice age. Arctic Anthropology 38(2):31-47.

STEPHENSON, R.O., GERLACH, S.C., GUTHRIE, R.D., HARINGTON, C.R., MILLS, R.O., and HARE, G. 2001. Wood bison in late Holocene Alaska and adjacent Canada: Paleontological, archaeological and historical records. In: Gerlach, S.C., and Murray, M.S., eds. People and wildlife in northern North America: Essays in honor of R. Dale Guthrie. BAR International Series 944. Oxford: British Archaeological Reports. 124-158.

STUIVER, M., and REIMER, P.J. 1993. Extended ${ }^{14} \mathrm{C}$ database and revised CALIB radiocarbon calibration program. Radiocarbon 35:215-230.

TORRENCE, R. 1983. Time budgeting and hunter-gatherer technology. In: Bailey, G., ed. Hunter-gatherer economy in prehistory: A European perspective. Cambridge: Cambridge University Press. 11-22. 
U.S. BUREAU OF INDIAN AFFAIRS. 1986. Preliminary site report on the McCurdy archeological site, GUL-100. Report submitted to the State Historic Preservation Officer. Report on file at the Alaska Office of History and Archaeology, 550 West 7th Avenue, Suite 1310, Anchorage, Alaska 99501.

VANDERHOEK, R., DILLEY, T.E., and HOLMES, C.E. 1997. North Gerstle Point: A deeply stratified multi-component site in the central Tanana Valley, Alaska. Paper presented at the 24th Annual Meeting of the Alaska Anthropological Association, Whitehorse.

VASIL'EV, S.A. 2001. The final paleolithic in northern Asia: Lithic assemblage diversity and explanatory models. Arctic Anthropology 38(2):3-30.

WARD, G.K., and WILSON, S.R. 1978. Procedures for comparing and combining radiocarbon age determinations: A critique. Archaeometry 20:19-31.

WEST, C.E. 1978. Archeology of the Birches site, Lake Minchumina, Alaska. MA thesis, University of Alaska Fairbanks.

WEST, F.H. 1967. The Donnelly Ridge site and the definition of an early core and blade complex in central Alaska. American Antiquity 32(3):360-382.

- 1972. Archeological and paleoecological research in the Tangle Lakes, central Alaska, 1966-1972. On file at the Office of History and Archaeology, 550 West 7th Avenue, Suite 1310, Anchorage, Alaska 99501.

1975. Dating the Denali complex. Arctic Anthropology $12: 76-81$.

- 1981. The archaeology of Beringia. New York: Columbia Press.

- 1996. Teklanika West. In: West, F.H., ed. American beginnings. Chicago: University of Chicago Press. 332-343.

WEST, F.H., ROBINSON, B.S., and CURRAN, M.L. 1996 a. Phipps Site. In: West, F.H., ed. American beginnings. Chicago: University of Chicago Press. 381-386.

WEST, F.H., ROBINSON, B.S., and WEST, C.F. 1996b. Whitmore Ridge. In: West, F.H., ed. American beginnings. Chicago: University of Chicago Press. 386-394.
WEST, F.H., ROBINSON, B.S., and DIXON, R.G. 1996c. Sparks Point. In: West, F.H., ed. American beginnings. Chicago: University of Chicago Press. 394-398.

WILSON, A.K., and SLOBODINA, N.S. 2007. Two Northern Archaic tent ring settlements at Agiak Lake, Central Brooks Range. Alaskan Journal of Anthropology 5(1):43-59.

WORKMAN, W.B. 1972. The cultural significance of a volcanic ash which fell in the Upper Yukon basin about 1400 years ago. Expanded version of a paper read at the International Conference on the Prehistory and Paleoecology of the Western American Arctic and Subarctic, Calgary. Paper on file at the Alaska Office of History and Archaeology, 550 West 7th Avenue, Suite 1310, Anchorage, Alaska 99501.

—_ 1976. Archeological investigations at GUL-077: A prehistoric site near Gulkana, Alaska. Report on file at the Alaska Office of History and Archaeology, 550 West 7th Avenue, Suite 1310, Anchorage, Alaska 99501.

1977. Ahtna archaeology: A preliminary statement. In: Helmer, J.W., Van Dyke, S., and Kense, F.J., eds. Problems in the prehistory of the North American Subarctic: The Athapaskan question. Calgary: University of Calgary Archaeological Association. 22-39.

1978. Prehistory of the Aishihik-Kluane area, southwest Yukon Territory. Mercury Series, Archaeological Survey of Canada Paper 74. Ottawa: National Museum of Man.

YESNER, D.R. 1996. Human adaptation at the Pleistocene-Holocene boundary (circa 13,000 to 8,000 BP) in eastern Beringia. In: Straus, L.G., Eriksen, B.V., Erlandson, J.M., and Yesner, D.R., eds. Humans at the end of the ice age: The archaeology of the Pleistocene-Holocene transition. New York: Plenum Press. $255-276$.

YESNER, D.R., and PEARSON, G.A. 2002. Microblades and migrations: Ethnic and economic models in the peopling of the Americas. In: Elston, R.G., and Kuhn, S.L., eds. Thinking small: Global perspectives on microlithization. Arlington: Archeological Papers of the American Anthropological Association Number 12. 133-161.

YI, S., and CLARK, G.A. 1985. The 'Dyuktai culture' and New World origins. Current Anthropology 26:1-20. 